DANMARKS GEOLOGISKE UNDERSØGELSE

II. Række. Nr. 112

Geological Survey of Denmark. II. Series. No. 112

\title{
Middle and Late Weichselian marine deposits at Nerre Lyngby, northern Jutland, Denmark, and their foraminiferal faunas
}

BY

Karen Luise Knudsen

DANSK SAMMENDRAG

Midt og sen Weichselien marine aflejringer

ved Nørre Lyngby, Nordjylland,

Danmark, og deres foraminifer-faunaer

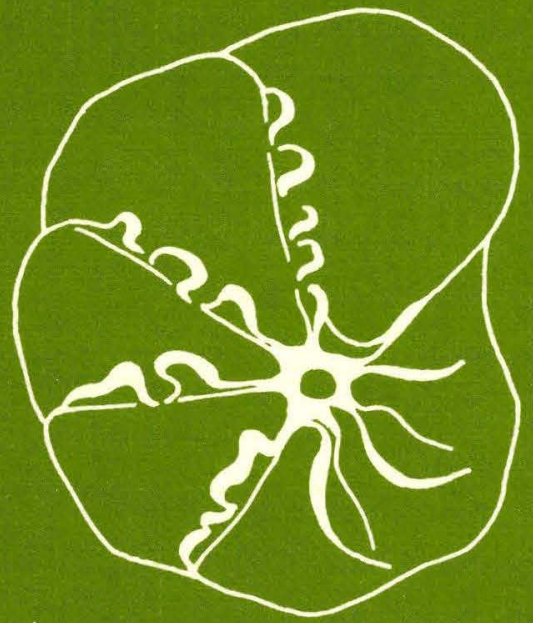

I kommision hos C. A. Reitzels Forlag. København 1978 


\section{Middle and Late Weichselian marine deposits at Nørre Lyngby, northern Jutland, Denmark, and their foraminiferal faunas}

By

Karen Luise Knudsen

Dansk sammendrag:

Midt og sen Weichselien marine aflejringer ved Nørre Lyngby, Nordjylland, Danmark, og deres foraminifer-faunaer

I kommission hos C. A. Reitzels Forlag København 1978 
D. G. U. II. rk. nr. 112

er sat med fotosats Times

og trykt i offset i 1000 eksemplarer

hos Andelsbogtrykkeriet i Odense.

Bogen er trykt på Thai-Cote, $115 \mathrm{~g}$

fra a/s De forenede Papirfabrikker.

ISBN 87-421-0718-0

ISSN 0366-9130

With 7 plates

Date of publication: $1978-11-11$ 


\section{Contents}

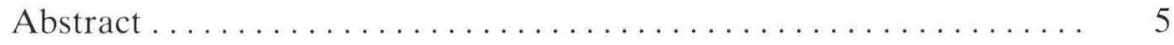

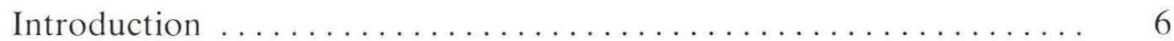

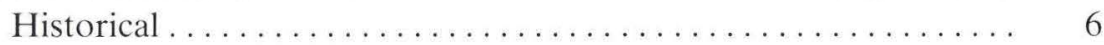

Material and methods ...................... 7

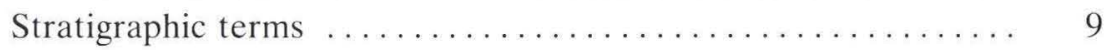

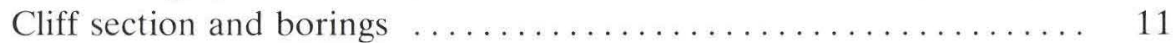

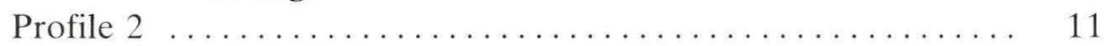

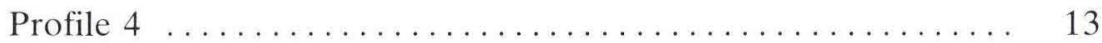

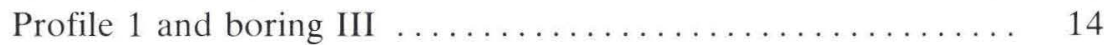

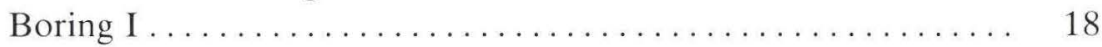

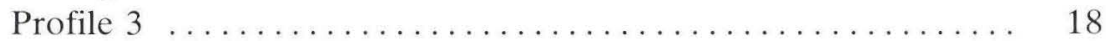

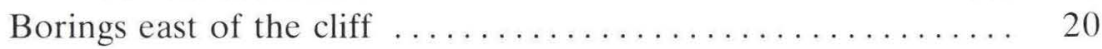

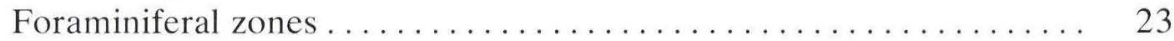

Description, palaeoecology and distribution ............ 23

The Bulimina marginata - Buccella frigida zone ......... 23

The Elphidium subarcticum zone ................ 23

The Elphidium excavatum zone ................. 24

The Elphidium albiumbilicatum zone ............. 25

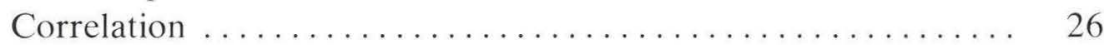

The Bulimina marginata - Buccella frigida zone ......... 26

The Elphidium subarcticum zone ................ 27

The Elphidium excavatum zone .................. 29

The Elphidium albiumbilicatum zone ............. 30

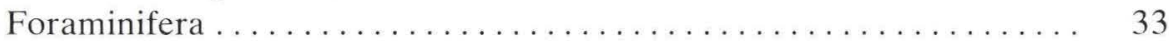

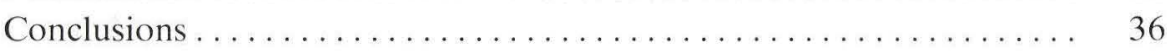

Acknowledgements ......................... 38

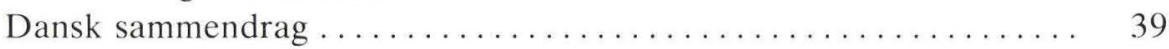

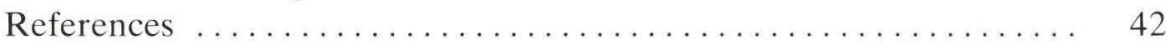

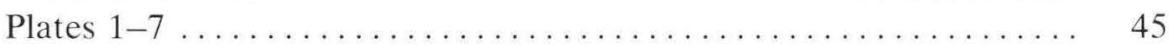




\section{Abstract}

The marine Weichselian deposits at Nørre Lyngby are subdivided into four assemblage zones based on the content of benthonic foraminifera.

The lowermost zone, the Bulimina marginata-Buccella frigida zone, is correlated with the upper part of the Older Yoldia Clay of Vendsyssel and inferred to be of Middle Weichselian interstadial age.

The Elphidium subarcticum zone is correlated with the Lower Saxicava Sand and the Elphidium excavatum zone with the Younger Yoldia Clay of Vendsyssel. The E. subarcticum zone is found to be a sandy facies within the lower part of the E. excavatum zone at Nørre Lyngby. The foraminiferal faunas of these two zones indicate mainly artic climatic conditions. Radiocarbon dates show that the E. subarcticum zone and also a major part of the $E$. excavatum zone belong to late Middle Weichselian.

The uppermost zone, the Elphidium albiumbilicatum zone, is correlated with the Upper Saxicava Sand. The foraminiferal faunas in this zone seem to indicate an amelioration in climate, and the deposit might represent the Late Weichselian Bølling interstadial. 


\section{Introduction}

\section{Historical}

Marine deposits in Vendsyssel containing arctic faunas were mentioned as early as 1828 by Pingel. Later Johnstrup (1882) described the molluscs in »undisturbed Yoldia Clay « at the locality of Nørre Lyngby (fig. 1), and Madsen (1895) mentioned a few foraminifera from that deposit. More detailed descriptions of the marine sediments at Nørre Lyngby were given by Jessen in 1899, 1918, 1931 and 1936. Jessen suggested that the deposits were of Late-glacial age, deposited in the Yoldia Sea, which transgressed the area during the Weichselian deglaciation. He found that the marine deposits in many parts of Vendsyssel consisted of three units, the Yoldia Clay itself and the two shallow water deposits, the Lower Saxicava Sand below and the Upper Saxicava Sand above the clay.

Because of isostatic adjustments of the area after the latest glaciation, these marine sediments now appear above sea level, and the surface of marine Late-glacial deposits forms the Yoldia plains. These plains surround the higher glacial highlands, which are composed mainly of glacial deposits but also of older marine sediments.

Jessen (1936) described two different types of the Younger Yoldia Clay in Vendsyssel. In the northern and eastern part the clay is rich in fossils, and its deposition presumably took place under normal marine conditions. In the southern and south-western part of Vendsyssel the clay is nearly unfossiliferous and is supposed to have been deposited in a brackish or even in a freshwater environment. He assumed these different ecological conditions to be caused by differences in meltwater supply from the melting ice cap to the areas of deposition.

The content of arctic molluscs led S. Hansen (1965) to place the Lower Saxicava Sand and the Younger Yoldia Clay of Vendsyssel in pollen zone I a (Oldest Dryas, according to Iversen 1942), and he also considered the Upper Saxicava Sand to be of Oldest Dryas age. Later Krog (1968) and Krog \& Tauber (1974) correlated the Lower Saxicava Sand and the Younger Yoldia Clay chronologically with Daniglacial time and pollen zone I a, and they presented radiocarbon dates from these deposits (see also Tauber 1966 a, 1966 b). There are no radiocarbon dates, which can with certainty be refer- 


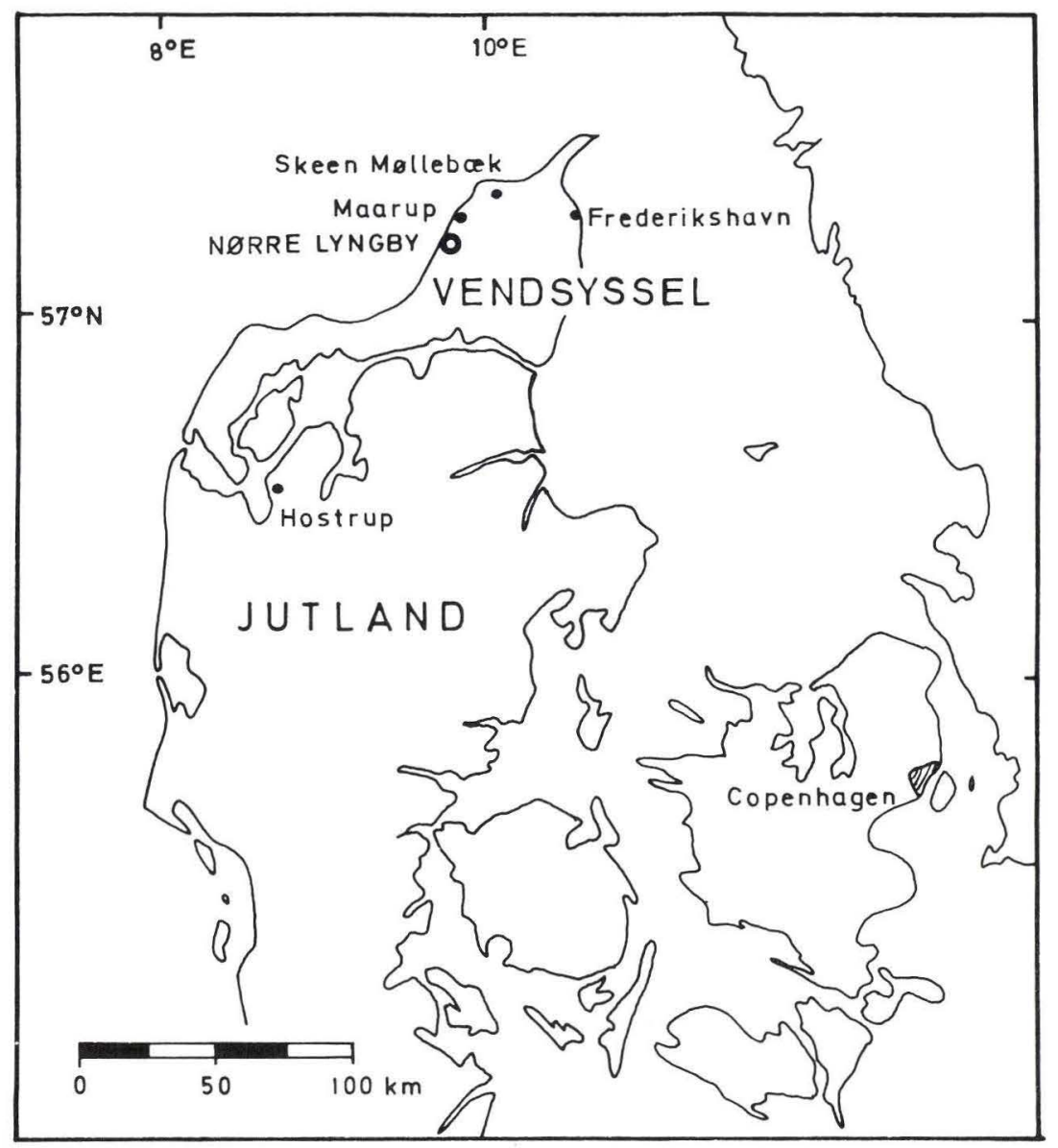

Fig. 1. Location map.

red to Upper Saxicava Sand, but this unit is usually considered to belong to Oldest Dryas time (Krog 1968, Krog \& Tauber 1974).

Foraminiferal faunas from marine Late-glacial deposits of different localities in Vendsyssel were earlier described by Jørgensen (1971) and Knudsen (1971), and Michelsen (1967) described foraminiferal faunas from corresponding deposits on the island of Læsø east of Vendsyssel.

Material and methods

Samples for the present investigation were collected partly from the coastal cliff at Nørre Lyngby and partly from borings on the beach at the foot of the cliff and in the adjacent area east of the cliff (figs. 2 and 3 ). 


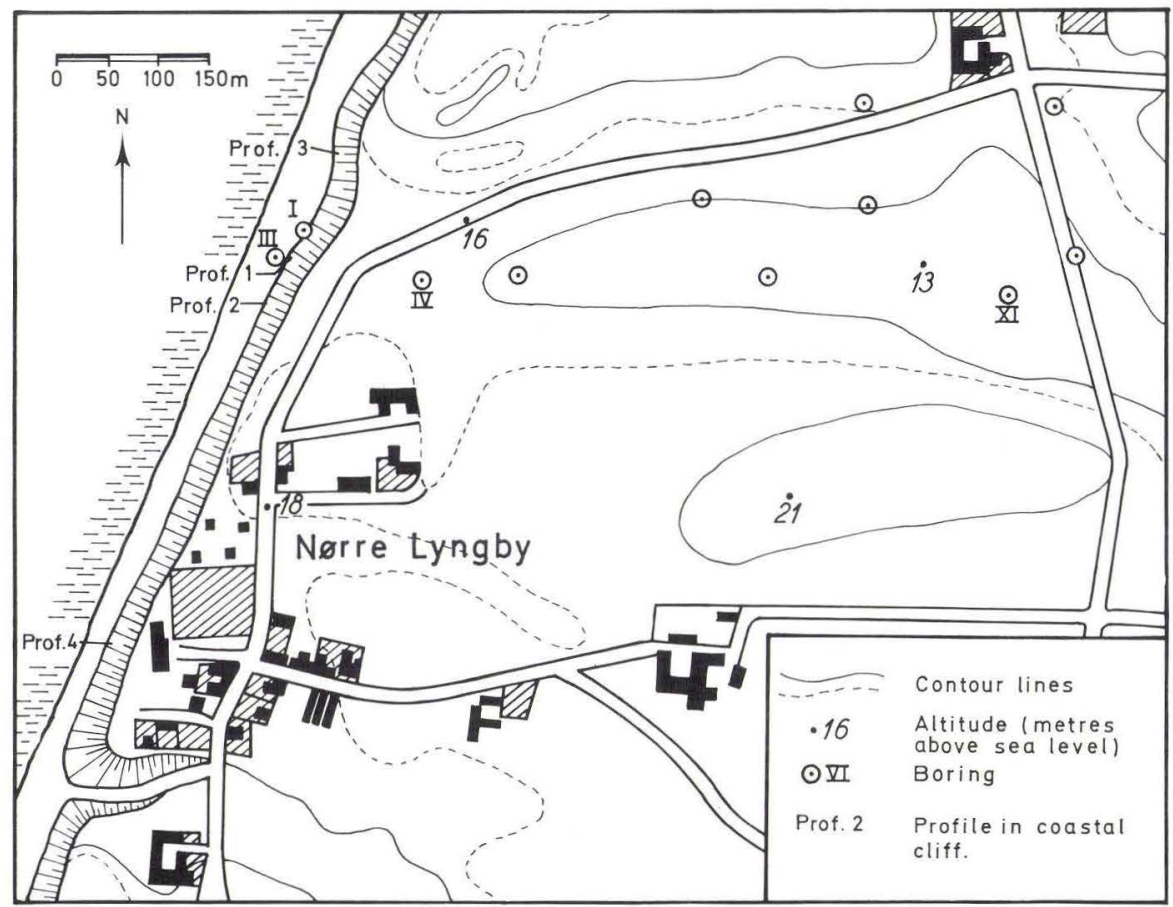

Fig. 2. Location of the borings and profiles in the Nørre Lyngby area. The numbered borings are described and the others just briefly mentioned in the present work. Map based on Geodetic Institute M 1217 I NØ Løkken.
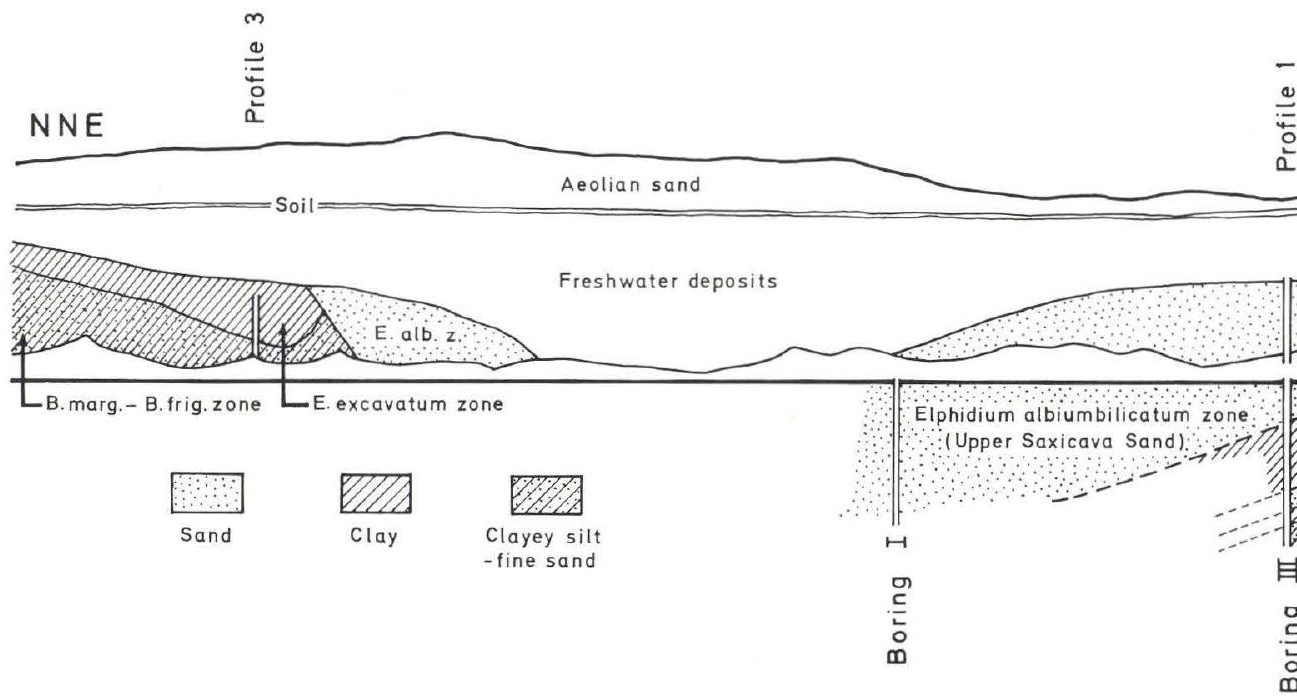

Fig. 3. Marine deposits in the cliff section at Nørre Lyngby and their continuation below the cliff. Locat 
Sand (Jessen 1918, 1936) are maintained, in spite of the fact that they are combinations of biostratigraphical and lithostratigraphical terms. In the present work the term Late-glacial is not used synonymous with the chronostratigraphical term Late Weichselian, but as a local environmental term for the deglaciation period, as used by Jessen $(1918,1936)$. 


\section{Cliff Section and Borings}

The deposits of the coastal cliff at Nørre Lyngby consist partly of marine clay and sand, partly of freshwater sediments. In the cliff section (fig. 3) the surface of the marine deposits forms a depression, which is about $200 \mathrm{~m}$ wide and $15 \mathrm{~m}$ deep. This basin structure is filled up with a complex series of freshwater deposits, which have been described by i.a. Jessen \& Nordmann (1915), Iversen (1942), Krog (1978) and M. R. Hansen (in prep.).

Foraminiferal faunas from a series of vertical profiles through the marine deposits in the coastal cliff at Nørre Lyngby have been analysed. Four of these profiles and four of the eleven borings in the area are described below.

\section{Profile 2}

Profile 2 is located about $100 \mathrm{~m}$ south of the centre of the freshwater basin (fig. 3). Lithology, grain size distribution and percentage distribution of selected species of foraminifera in profile 2 are shown in fig. 4. In the lower part of the profile, the sediments consist of clay and sandy clay with thin layers and lenses of sand. At about $11.0 \mathrm{~m}$ above sea level there is a sharp change to a sandy sequence above. The upper c. $2 \mathrm{~cm}$ of the clay is wethered and contains a few pebbles and shell fragments, suggesting a local break in sedimentation.

The foraminiferal faunas of the clayey sequence (samples no. 1-8) are characterized by very high dominance of Elphidium excavatum, forma clava$t a$, which accounts for 78-95\% of the total faunas. Cassidulina crassa varies from 2 to $6 \%$, and Elphidium albiumbilicatum increases from less than $1 \%$ in the lower samples to $7 \%$ in samples 7 and 8 . Elphidium subarcticum occurs in all the samples, but usually with frequencies not higher than $1 \%$. Accessory species are Bulimina marginata, Islandiella norcrossi, Elphidium asklundi, Buccella frigida and a few others. The faunal diversities of these assemblages are usually only $2-4$ with a maximum of 6 . The foraminiferal faunas in these samples represent an assemblage zone, which is here called the Elphidium excavatum zone. 


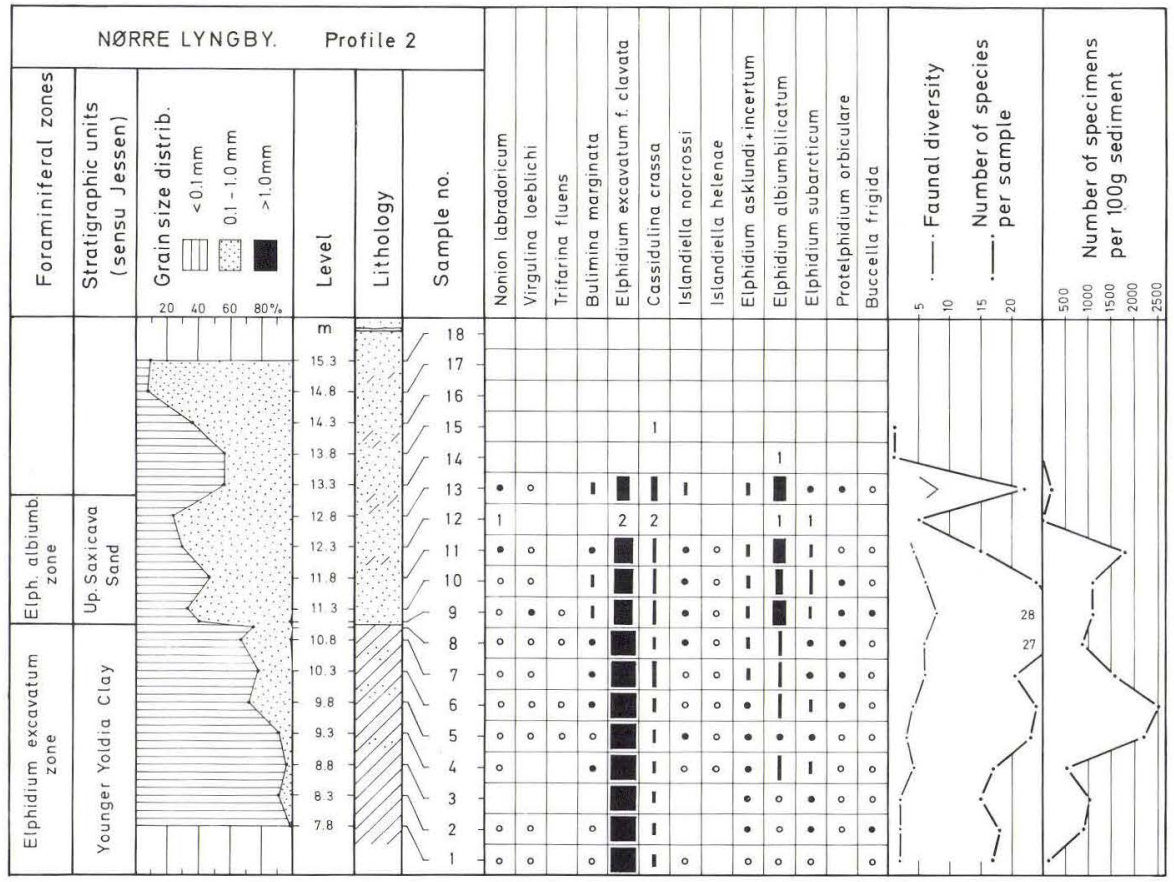

Fig. 4. Range chart for profile 2 from the cliff section. Legend for lithology in fig. 3 and for foraminiferal frequencies in fig. 6 .

In the samples no. 9-13 from the sandy sequence of profile 2 Elphidium excavatum, forma clavata is still the dominant species, but the frequencies are lower $(37-56 \%)$ than in the samples of the underlying clay. Elphidium albiumbilicatum is second in number with $20-31 \%$ of the total faunas, and Bulimina marginata, Cassidulina crassa, Elphidium asklundi and E. subarcticum are common. These faunas are characterized by the high content of the species E. albiumbilicatum, and also by higher faunal diversities than the $E$. excavatum zone faunas. The present assemblage zone is here called the Elphidium albiumbilicatum zone.

The marine sequence of profile 2 is overlain by a non-marine sequence of sand covered by a thin humus layer (soil) at about $15.8 \mathrm{~m}$ above sea level. Aeolian sand occurs at the top. 


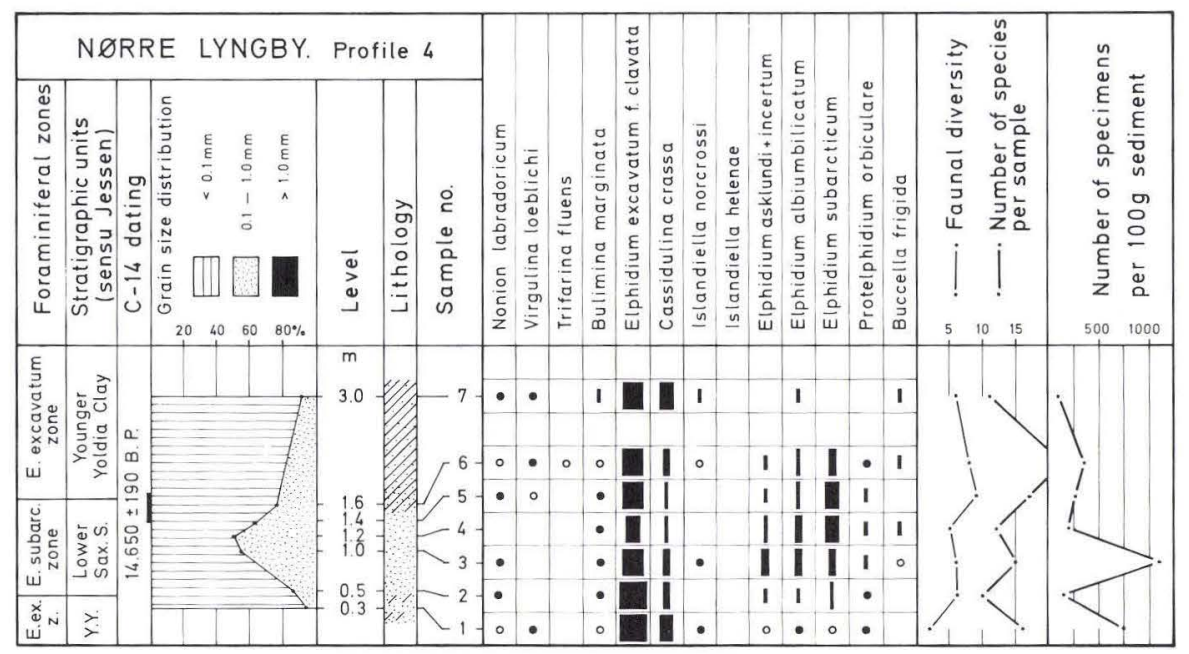

Fig. 5. Range chart for profile 4 from the cliff section. Legend for lithology in fig. 3 and for foraminiferal frequencies in fig. 6.

\section{Profile 4}

South of profile 2 the coastal cliff mainly consists of horizontally stratified clay containing foraminiferal faunas as described from the lower part of profile 2. The deposit thus represents the Elphidium excavatum zone. At a distance of about $400 \mathrm{~m}$ south of the centre of the freshwater basin (fig. 3) the clay starts dipping to the south and is again covered by a sandy deposit of variable thickness. The foraminiferal faunas show that this sand represents the Elphidium albiumbilicatum zone, which was described from the upper part of profile 2. Contrary to profile 2 there is a gradual transition between clay and sand in this southern part of the cliff section. The upper part of the clay deposit contains an increasing number of sandy and silty layers of $<1$ to $5 \mathrm{~cm}$ thickness, and the lower part of the sandy sequence usually contains a few layers of clay and sandy clay.

A series of samples for foraminiferal analysis (profile 4, fig. 3) was collected from the lowermost part of the coast cliff about $470 \mathrm{~m}$ south of the centre of the freshwater basin, and about $160 \mathrm{~m}$ north of a ramp leading to the beach from the village of Nørre Lyngby. The lithology and the distribution of selected species of foraminifera are shown in the range chart, fig. 5. The sediment is sandy clay in the lowermost part of the section, grading into a sand deposit of about $1 \mathrm{~m}$ thickness. At about $1.5 \mathrm{~m}$ above sea level there is a sharp change in sediment to clay containing a few thin sandy layers and lenses. 
The foraminiferal faunas from the clayey parts of the profile, i.a. the lowermost and of the uppermost sample (no. 1 and no. 7) have high dominances of Elphidium excavatum, forma clavata, and Cassidulina crassa is second in number. Sample no. 1 contains few other species, and its faunal diversity is only 2. The uppermost sample (no. 7) has a higher content of accessory species, i.a. Bulimina marginata, Islandiella norcrossi, Elphidium albiumbilicatum and Buccella frigida, and its faunal diversity is 6. The faunas in this upper and lower part of the sequence are characteristic of the Elphidium excavatum zone, and this assemblage zone is found to continue in the upper part of the cliff section, above sample 7 in profile 4 . The thickness of the $E$. excavatum zone is here about $8-10 \mathrm{~m}$.

In the sand deposit, represented by samples 2-6, the frequency of Elphidium excavatum, forma clavata is lower (38-61\%). Cassidulina crassa gradually becomes less frequent than in the clayey deposits, whereas some other species are rather common in these samples, viz., Elphidium asklundi (2-12 $\%$ ), E. albiumbilicatum (4-15\%), E. subarcticum (6-27\%) and Protelphidium orbiculare (1-3\%). The faunal diversity varies from 6 to 9 . The assemblage zone represented by these five samples in profile 4 is here called the Elphidium subarcticum zone. This zone thus occurs within the lower part of the Elphidium excavatum zone in profile 4.

\section{Profile 1 and boring III}

The samples of profile 1 were collected about $55 \mathrm{~m}$ south of the centre of the freshwater basin (fig. 3). The lithology and the distribution of selected species of foraminifera are shown in the range chart, fig. 6 . The foraminiferal faunas of samples $1-10$ in profile 1 are dominated by Elphidium excavatum, forma clavata (38-70\%). Cassidulina crassa and Elphidium albiumbilicatum are frequent, accounting for $11-25 \%$ and $2-36 \%$ of the faunas respectively. The most common accessory species are Bulimina marginata, Islandiella norcrossi, Elphidium asklundi, E. albiumbilicatum, Protelphidium orbiculare and Buccella frigida. The faunal diversity varies from 4-11 and the number of specimens is usually less than 500 per $100 \mathrm{~g}$ sediment. These faunas are characteristic of the Elphidium albiumbilicatum zone, and the deposit corresponds to that of the upper part of the marine sequence of profile 2, about 45 $\mathrm{m}$ farther south (fig. 3). The specimens of foraminifera in samples 11 and 12 of profile 1 are worn and etched, and are presumably reworked.

In order to investigate the continuation of the marine sequence at this locality, boring III was made on the beach just below profile 1 , at the foot of the coastal cliff. The lithology and foraminiferal content of samples from the 


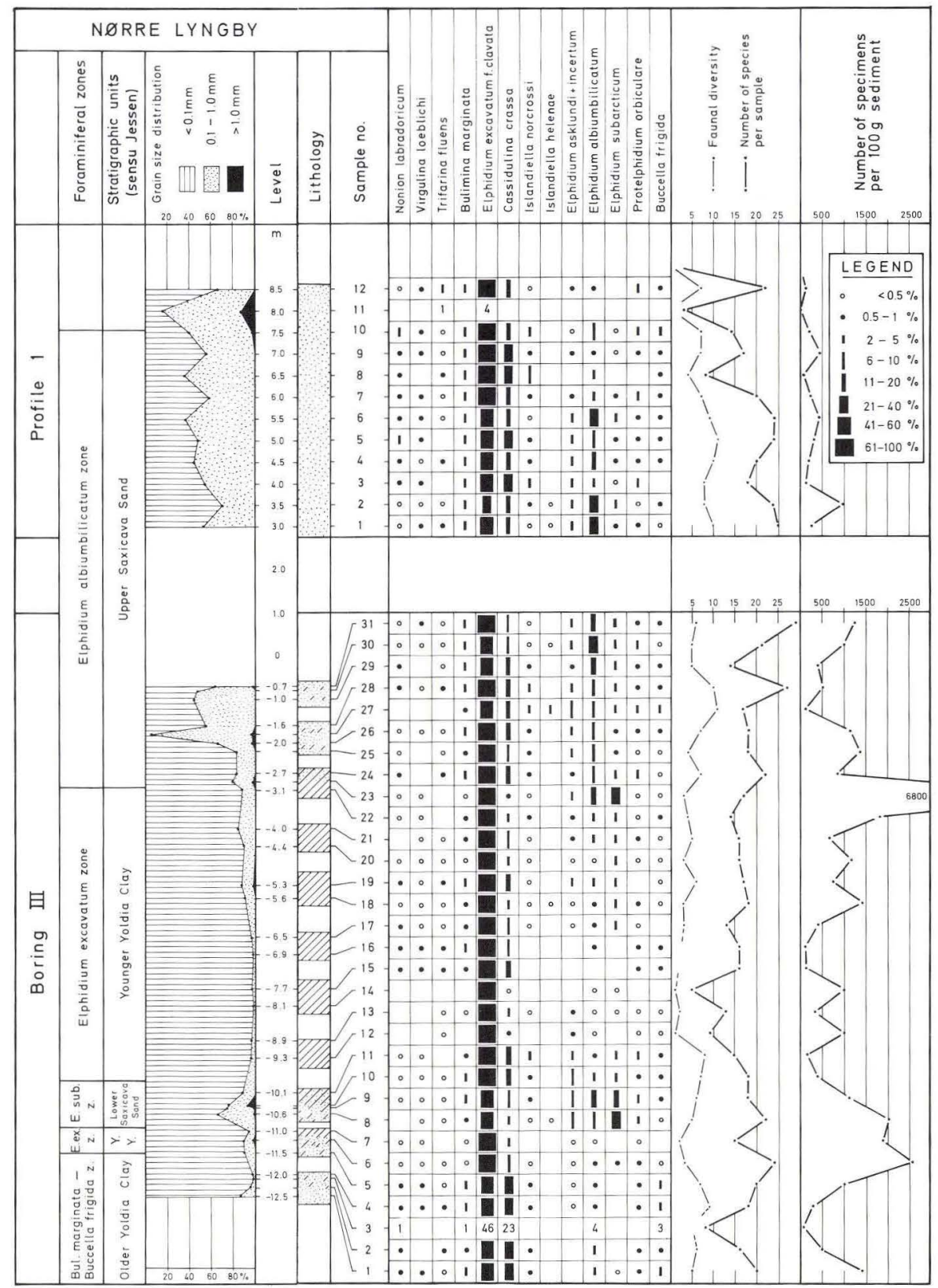

Fig. 6. Range chart for profile 1 from the cliff section and for boring III sited on the beach just below the profile. For poor foraminiferal faunas the entire number of specimens of each species is entered in the species columns instead of the percentages. Legend for lithology in fig. 3 . 
boring are given in a combined range chart for profile 1 and boring III (fig. 6). The upper part of boring III consists of sand with Elphidium albiumbilicatum zone faunas down to about $3 \mathrm{~m}$ below sea level, i.e. samples no. 23-31. There is a gradual change in sediment from this sand with a few thin layers of clay in the upper part of the boring through a series of alternating layers of sand and clay to clay with a few thin layers and lenses of sand. The clayey series, has a thickness of about $7 \mathrm{~m}$ (samples no. 12-22) and contains foraminiferal faunas similar to those characterizing the Elphidium excavatum zone of profile 2, with very high dominances of Elphidium excavatum, forma clavata.

Below the clay (the Elphidium excavatum zone) is a sandy layer with foraminiferal faunas characterized by relatively high frequencies of Elphidium subarcticum. In the four samples (no. 8-11) from that layer E. subarcticum accounts for 5-34\% of the total fauna, whereas Elphidium excavatum, forma clavata is still the dominant form comprising $45-63 \%$ of the fauna. Other frequent species are Cassidulina crassa (4-18\%), Elphidium asklundi (2-9 \%), E. albiumbilicatum (1-11\%) and Protelphidium orbiculare (1-2 $\%$ ). This is the characteristic composition of faunas in the Elphidium subarcticum zone as described from profile 4 , about $400 \mathrm{~m}$ to the south. The succession of faunas in the present sandy sequence corresponds closely to that of samples 2-6 in profile 4 . Below this sandy sequence of boring III there is another clayey layer (samples 6 and 7) containing foraminiferal faunas typical of the E. excavatum zone. The sandy sequence, the E. subarcticum zone, thus appears to be a sandy facies within the lowermost part of the clay, the E. excavatum zone, as in profile 4.

The sediment of the lowermost $1.2 \mathrm{~m}$ of boring III consists of light olive-grey fine sand with some layers of clayey sand.The samples 1-5 from this deposit contain foraminiferal faunas characterized by very small but well preserved specimens, indicating a primary position and accordingly a marine formation. The foraminiferal faunas are dominated by the two species Elphidium excavatum, forma clavata (50-56 \%) and Cassidulina crassa (32-38 $\%$ ). Accessory species are Bulimina marginata, Buccella frigida, Protelphidium orbiculare, Elphidium albiumbilicatum, Islandiella norcrossi, Nonion labradoricum and Virgulina loeblichi. The faunal diversity varies from 5 to 9 , and the number of specimens per $100 \mathrm{~g}$ sediment from 50 to 1400 . These faunas represent an assemblage zone, which is here called the Bulimina marginata-Buccella frigida zone. 


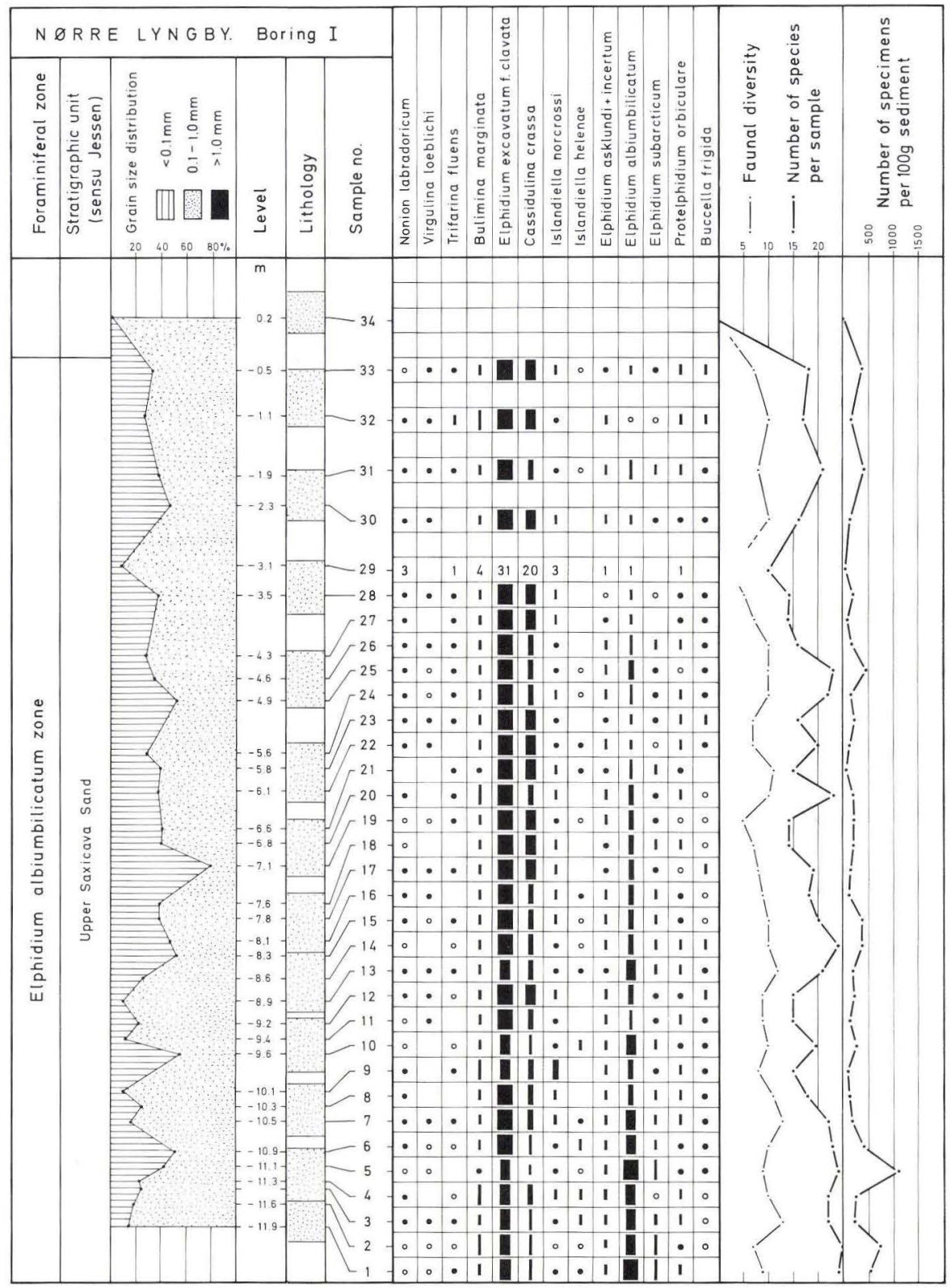

Fig. 7. Range chart for boring I at Nørre Lyngby. Legend for lithology in fig. 3 and for foraminiferal frequencies in fig. 6 . 


\section{Boring I}

The site of boring $\mathrm{I}$ is about $20 \mathrm{~m}$ south of the centre of the freshwater basin (fig. 3). The boring was made on the beach just below the cliff section. It was $12.9 \mathrm{~m}$ deep and through the whole sequence the sediment consisted of light olive-grey fine sand with scattered thin layers of olive-grey clay. The lithology, the grain size distribution and the percentage distribution of selected species of foraminifera are shown in fig. 7.

The foraminiferal faunas of the 34 analysed samples from boring I were rather uniform with Elphidium excavatum, forma clavata, E. albiumbilicatum and Cassidulina crassa as the three dominant species. Common accessory species are Bulimina marginata, Islandiella norcrossi, Elphidium asklundi, E. subarcticum, Protelphidium orbiculare and Buccella frigida. This faunal composition indicates that the whole sequence of boring I belongs to the Elphidium albiumbilicatum zone. The lower boundary of the zone was not reached at $12.0 \mathrm{~m}$ below sea level at the locality. As the upper boundary was found in the cliff at about $2 \mathrm{~m}$ above sea level, the thickness of the E. albiumbilicatum zone at boring $\mathrm{I}$ is at least $14 \mathrm{~m}$.

\section{Profile 3}

The marine deposits, which mostly occur below sea level at boring I, are again found at a high level in the cliff section north of that boring (fig. 3). The marine deposits are considerably disturbed in this part of the cliff. A series of samples from profile 3 in the cliff section, about $55 \mathrm{~m}$ north of boring I, was analysed for the content of foraminifera. Three samples from the lower clayey sand and silt of profile 3 contained from 360 to 540 specimens of small but well preserved foraminiferal tests per $100 \mathrm{~g}$ sediment. One of these samples contained the fauna listed on p. 19 in $110 \mathrm{~g}$ sediment.

The faunal diversity is 7 and the number of specimens 440 per $100 \mathrm{~g}$ sediment. This composition of fauna is similar to those found in the lowermost part of boring III below the E. excavatum zone and the E. subarcticum zone, and the present deposit belongs to the Bulimina marginata-Buccella frigida zone.

Lying above the clayey sand and silt in profile 3 is an olive-grey clay with thin layers and lenses of fine sand. This clay contains foraminiferal faunas similar to those in the E. excavatum zone of the area. They have very high dominances of Elphidium excavatum, forma clavata (92-99\%). Cassidulina crassa is second in number, and the faunal diversities are 1-2. The E. exca- 
Nørre Lyngby, profile 3 (spl. no. 3). Coll. Knudsen, 1974.

\begin{tabular}{|c|c|c|}
\hline Species & Frequency & Percentage \\
\hline Elphidium excavatum, forma clavata $\ldots \ldots \ldots \ldots \ldots \ldots$ & 261 & 54 \\
\hline Cassidulina crassa .......................... & 160 & 33 \\
\hline 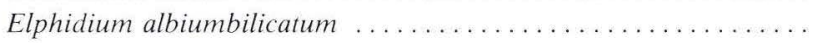 & 12 & 3 \\
\hline 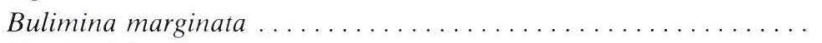 & 11 & 2 \\
\hline 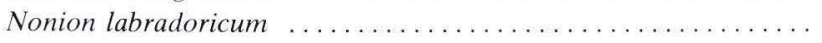 & 7 & 1 \\
\hline 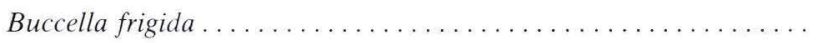 & 6 & 1 \\
\hline 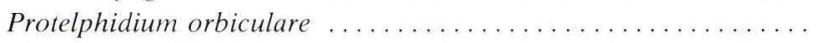 & 5 & 1 \\
\hline 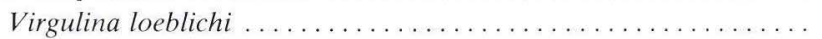 & 4 & 1 \\
\hline 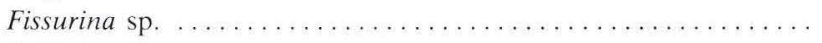 & 3 & 1 \\
\hline 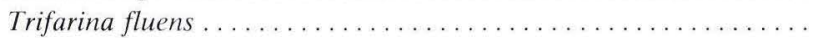 & 3 & 1 \\
\hline 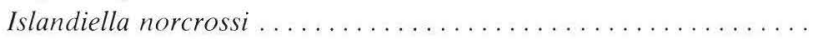 & 2 & $<1$ \\
\hline 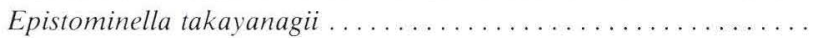 & 2 & $<1$ \\
\hline 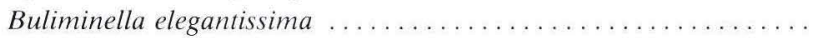 & 1 & $<1$ \\
\hline 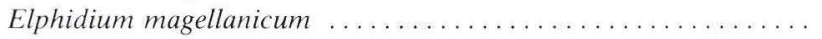 & 1 & $<1$ \\
\hline Ammonia batavus . . . . . . . . . . . . . . . . . . & 1 & $<1$ \\
\hline 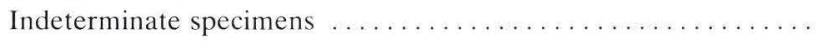 & 1 & $<1$ \\
\hline
\end{tabular}

Total

480

vatum zone is only up to $5 \mathrm{~m}$ thick in this northern part of the cliff, and as mentioned these layers are disturbed.

From about $10 \mathrm{~m}$ to about $30 \mathrm{~m}$ south of profile 3 in the cliff the $B$. marginata- $B$. frigida zone and the $E$. excavatum zone are overlain by a tilted unit of sand (fig. 3), in which the beds dip steeply southwards. Foraminiferal analysis of samples from this deposit show that it belongs to the E. albiumbilicatum zone. The sedimentary structures of both the marine and the freshwater deposits at the locality will be further discussed by M. R. Hansen (in prep.).

North of profile 3 the marine deposits overlie glaciofluvial sand and clay, and gradually these fluviatile sediments make up most of the cliff section (the diluvial sand and clay of Jessen 1931). The glaciofluvial deposits contain some foraminifera, but they are usually poorly preserved, and large robust forms seem to be overrepresented. These foraminiferal tests are therefore considered reworked. 


\section{Borings east of the coastal cliff}

Boring IV is located about $125 \mathrm{~m} \mathrm{ESE}$ of boring I (fig. 2). The bore site lies c. $15.0 \mathrm{~m}$ above sea level, and the depth of the boring is $14.5 \mathrm{~m}$. Lithology and distribution of selected species of foraminifera are shown in fig. 8. The foraminiferal analyses show that the lowermost $6 \mathrm{~m}$ of boring IV consist of marine deposits. There is a gradual change in sediment through the marine

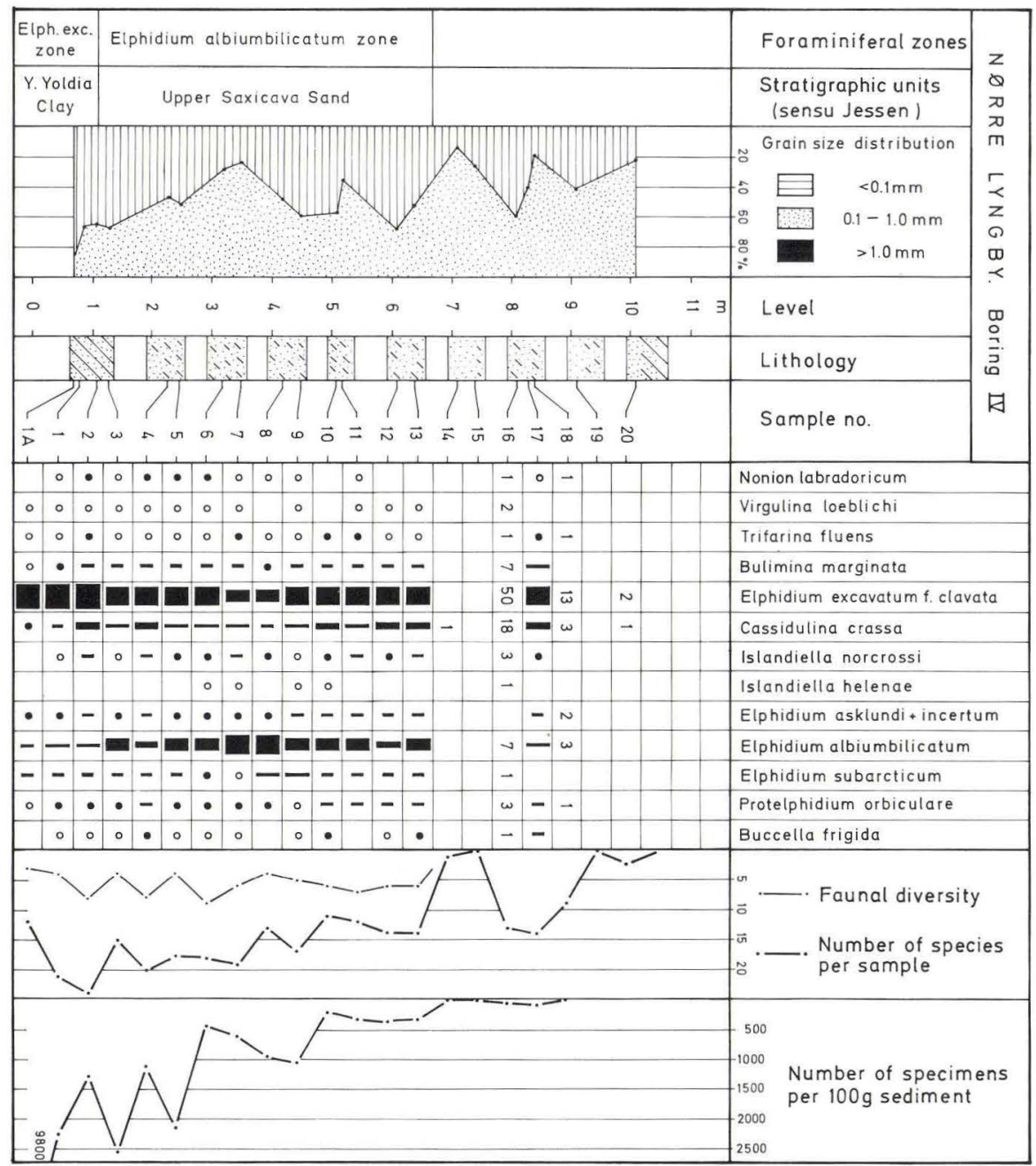

Fig. 8. Range chart for boring IV at Nørre Lyngby. Legend for lithology in fig. 3 and for foraminiferal frequencies in fig. 6 . 


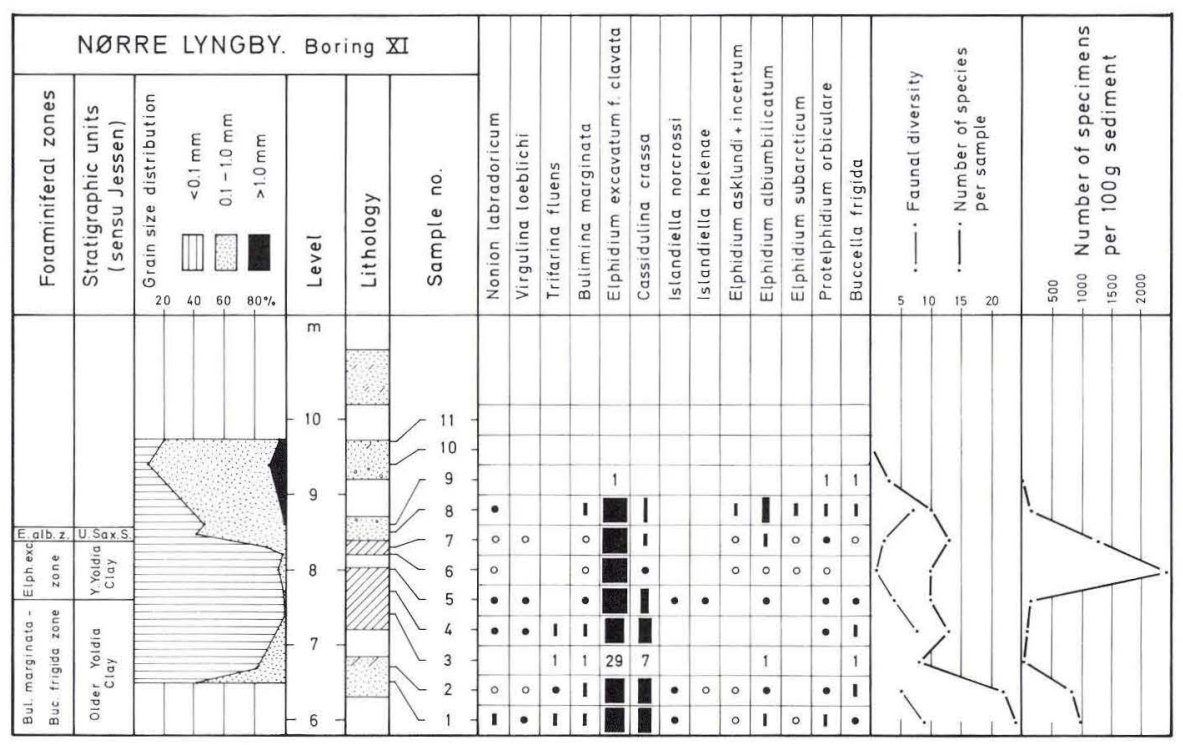

Fig. 9. Range chart for boring XI at Nørre Lyngby. Legend for lithology in fig. 3 and for foraminiferal frequencies in fig. 6 .

sequence from a sandy clay in the lowermost part to a sandy deposit with scattered thin clay layers in the major part of the sequence. The lower sandy clay contains foraminiferal faunas, which are characteristic for the E. excavatum zone of the area. There is a very high dominance of E. excavatum, forma clavata in samples from this lower deposit. The content of E. albiumbilicatum in the faunas gradually increases from $4 \%$ in the lowermost sample to $16-45 \%$ in samples $3-13$, indicating that these represent the E. albiumbilicatum zone of the area.

The marine sequence in boring IV is overlain by $8.5 \mathrm{~m}$ of freshwater sediments. There are a few foraminifera in the samples 14-20, but they are badly preserved and are considered to have been redeposited.

Boring XI is located about $700 \mathrm{~m}$ east of boring I (fig. 2). The bore site lies c. $14.5 \mathrm{~m}$ above sea level and the depth of the boring is $8.0 \mathrm{~m}$. Lithology and distribution of selected species of foraminifera are shown in the range chart, fig. 9. The foraminiferal content in the lower $2.5 \mathrm{~m}$ of boring XI shows that these are marine deposits. The lower part is referred to the $B$. marginata- $B$. frigida zone, whereas the upper part represents the E. excavatum zone and the E. albiumbilicatum zone. The marine sequence in the boring is overlain by about $5 \mathrm{~m}$ freshwater sediments.

As shown on the location map, fig. 2, seven additional borings were carried 
out north of borings IV and XI. Three of them only contained freshwater deposits, but the four borings in the northeastern part of the area contained glaciofluvial deposits and marine silt and sandy clay below the freshwater sediments. Only the Bulimina marginata-Buccella frigida zone was represented here. 


\section{Foraminiferal zones}

\section{Description, palaeoecology and distribution}

The Bulimina marginata - Buccella frigida zone

The foraminiferal assemblages of this zone are dominated by the two species Elphidium excavatum, forma clavata and Cassidulina crassa. The most common and characteristic accessory species are Bulimina marginata, Buccella frigida, Nonion labradoricum, Islandiella norcrossi, Elphidium albiumbilicatum, Protelphidium orbiculare and Virgulina loeblichi. The faunal diversity is usually 5-8 and the number of specimens only about $200-700$ per $100 \mathrm{~g}$ sediment. The foraminiferal faunas of this assemblage zone are mainly arctic, but with a content of some boreal species.

The sediment of the $B$. marginata- $B$. frigida zone consists mainly of clayey silt or fine sand, but in some places also of sandy clay. This assemblage zone is found in the deeper parts of borings III and XI and also in some borings in the northeastern part of the area examined. The deposit occurs in the northern part of the cliff section below the E. excavatum zone. The thickness of the zone is not known.

The Elphidium subarcticum zone

The foraminiferal faunas of this assemblage zone are dominated by Elphidium excavatum, forma clavata. Frequent species are Cassidulina crassa, Elphidium subarcticum, E. albiumbilicatum, E. asklundi and Protelphidium orbiculare. The high content of E. subarcticum is particularly characteristic of this zone. The faunal diversity varies from 5 to 8 . An assemblage from the $E$. subarcticum zone is shown in plate 6, fig. 2. The faunas are shallow-water faunas indicating mainly arctic marine ecological conditions. However, the presence of E. albiumbilicatum in the faunas may indicate that the climate was not high-arctic.

The sediment of the present zone is mainly sand. It is found in boring III and in profile 4 of the Nørre Lyngby area, and the thickness is only about 1.5 $\mathrm{m}$. In both localities the zone is clayey in its lower part, and it occurs within the E. excavatum zone. 
The Elphidium excavatum zone

The foraminiferal faunas of the E. excavatum zone are characterized by very high dominance of the arctic form Elphidium excavatum, forma clavata, usually accounting for more than $85 \%$ of the total fauna. Cassidulina crassa is second in number and in most of the faunas there are a few specimens of Nonion labradoricum, Bulimina marginata, Elphidium asklundi, E. albiumbilicatum and E. subarcticum. The faunal diversity is generally only $1-2$, which is much lower than for the other assemblage zones of the area. An assemblage from the E. excavatum zone is shown in plate 6, fig. 1 .

The faunas of the E. excavatum zone are arctic and the low faunal diversity indicates extreme marine ecological conditions. According to G. Vilks (pers. com.) the faunas are similar to recent foraminiferal faunas in stagnant basins of the arctic seas north of Canada, and according to J. Nagy (pers. com.) corresponding recent faunas are also recorded from sheltered lagoonal areas of Spitsbergen. During deposition of the E. excavatum zone at Nørre Lyngby the water was probably deeper then during deposition of the E. subarcticum zone, but more stagnant marine conditions might have been of greater importance for the difference in faunal composition.

The sediment of the E. excvatum zone consists of olive-grey clay usually with many thin sandy layers and lenses. The foraminiferal faunas in the thin sandy layers differ somewhat from those in the clay itself. In the lowermost part of the deposit the sand layers contain higher frequencies of the two species Elphidium asklundi and E. subarcticum and also some specimens of E. albiumbilicatum and Protelphidium orbiculare. The compositions of such faunas are similar to those of the E. subarcticum zone. Higher in the sequence of the $E$. excavatum zone, $E$. asklundi still occurs in the sandy layers, $E$. subarcticum is less common, whereas E. albiumbilicatum gradually becomes more common. All these species must in one way or another be connected with the deposition of sand instead of clay. They may either be dependent on sand directly as a substrate, or their occurrence may be caused by additional oxygen content or food supply during periods of better water circulation. The sand material and the foraminifera may also have been transported together into the present areas of clay deposition from more sandy shallow-water deposits by annual melting of inshore ice, or during periods of greater water circulation. The sand laminae perhaps reflect some kind of cyclic variation, although they do not resemble varves in the proper sense.

The faunal change in the sand laminae from subarcticum faunas in the lower part to albiumbilicatum faunas in the upper part of the E. excavatum zone is probably caused by a gradual amelioration in climate. It may also indicate a gradual lowering of the salinity, as the shallow-water species $E$. albiumbilicatum also tolerates lowered salinity. 
E. subarcticum is a common species in arctic faunas. It was originally described from recent shallow-water faunas off the New England coast (Cushman 1944). E. albiumbilicatum was originally described from the interglacial Gardiners Clay, New York (Weiss 1954), and the species is common in recent boreal shallow and brackish water faunas (Lutze 1965). These two species are usually easily distinguishable, but in the present faunas from Nørre Lyngby there are often some difficulties in separating them. Some specimens clearly belong to E. subarcticum, others to E. albiumbilicatum, but transitional forms were found. Similar problems were also seen in faunas of the upper sandy part of the Hostrup Clay, which is inferred to represent the climatic amelioration near the end of the Elsterian Ice age (Knudsen 1977), and in the Zirfaea Beds of Bølling interstadial age (Jørgensen 1971 and Knudsen in prep.). Further investigations of the recent distributions of these two species and of living specimens in cultures might show that they are geographical variants of one species, E. subarcticum representing the arctic from the E. albiumbilicatum zone are shown in plate 7, figs. 1-2.

The E. excavatum zone is found as a nearly horizontally stratified deposit in the southern part of the cliff section at Nørre Lyngby. The thickness is from about 7 to more than $15 \mathrm{~m}$. Close to the basin structure the layers dip to the north (fig. 3), and in boring I near the central part of the depression the present zone was not reached at $12.0 \mathrm{~m}$ below sea level. North of the depression the E. excavatum zone is again found in the cliff section, but here it is only from less than one to a few metres thick. According to the borings the succession of strata seems to be the same in the area east of the coastal cliff.

\section{The Elphidium albiumbilicatum zone}

The foraminiferal faunas of this assemblage zone are characterized by high frequencies of Elphidium albiumbilicatum. Elphidium excavatum, forma clavata is dominant, and common species are Cassidulina crassa, Bulimina marginata, Elphidium asklundi and E. subarcticum. The faunal diversities are higher than for the E. excavatum zone, usually about 5-10. Assemblages from the E. albiumbilicatum zone are shown in plate 7, figs. 1-2.

The sediment of the E. albiumbilicatum zone consists of sand with clayey layers in the lower part. The faunal composition together with the sandy sediment indicate changed environmental conditions compared to the conditions during deposition of the E. excavatum zone. The water was probably shallower, and a higher current velocity may have played an important role both for sediment and faunas. The increasing frequency of $E$. albiumbilicatum through the sand laminae in the uppermost part of the E. excavatum zone and in the E. albiumbilicatum zone are assumed to indicate rising temperatures, and perhaps also lowering salinities. 
The E. albiumbilicatum zone is found above the E. excavatum zone at Nørre Lyngby. There is often a gradual transition from one zone to the other, both in sediment and fauna.

There is a remarkable increase in thickness of the E. albiumbilicatum zone towards the central part of the basin structure. The zone is only $2 \mathrm{~m}$ thick in profile 2 , increasing to $10.5 \mathrm{~m}$ in the combined sequence of profile 1 and boring III and more than $14 \mathrm{~m}$ in boring I (fig. 3). The level of the upper boundary of this uppermost marine zone decreases from $13 \mathrm{~m}$ above sea level in profile 2 to $7.5 \mathrm{~m}$ a.s.l. in profile 1 and to about $2 \mathrm{~m}$ a.s.l. in boring I. The present foraminiferal zone is again found at a higher level in the cliff section north of boring I (fig. 3). This is believed to indicate a continuous sinking of the central part of this depression during deposition, as discussed later.

East of the coastal cliff the E. albiumbilicatum zone is only found in borings IV and XI in the southern part of the investigated area, also here beneath freshwater deposits.

\section{Correlation}

The Bulimina marginata - Buccella frigida zone

This zone, which is found in the northern part of the cliff section and in the lowermost part of several borings in the Nørre Lyngby area, is also described from a boring at Rubjerg about $2 \mathrm{~km}$ east of Nørre Lyngby (Abrahamsen \& Knudsen in press). This assemblage zone may be correlated with part of the Older Yoldia Clay of Vendsyssel.

The composition of faunas are not exactly the same as in the Older Yoldia Clay, but they indicate marine ecological conditions corresponding to those indicated by the zone A faunas of the Older Yoldia Clay at Hirtshals (Andersen 1971) and the zone I faunas of the Skærumhede sequence (Konradi \& Knudsen 1974, Knudsen 1976). These zones are correlated with the Middle Weichselian Sandnes interstadial, described by Feyling-Hanssen (1966, 1971, 1974). The foraminiferal faunas in all these deposits are mainly arctic, but with some boreal species. They thus indicate a milder period during the Middle Weichselian. Shell samples from the Sandnes Clay of the Sandnes-Jæren area have been radiocarbon dated at $>23,000$ B.P. and 28,000-42,000 B.P. (Feyling-Hanssen 1974). These ages indicate that the Sandnes interstadial correlates with the Hengelo and Denekamp interstadials of the Netherlands (van der Hammen et al. 1971). A few specimens of Hiatella arctica have been found in the B. marginata-B. frigida zone at Nørre Lyngby, but not enough for radiocarbon dating. 
The Elphidium subarcticum zone

The foraminiferal assemblage of the Elphidium subarcticum zone at Nørre Lyngby compares well with faunas from the Lower Saxicava Sand at Maarup about $6 \mathrm{~km}$ farther north in the cliff section (Jessen 1931, pl. II, post 26-36). A sample from this Lower Saxicava Sand contained the following foraminiferal species in $67 \mathrm{~g}$ sediment:

Lønstrup coast cliff, Maarup. Coll. Knudsen, 1969.

\begin{tabular}{|c|c|c|}
\hline Species & Frequency & Percentage \\
\hline 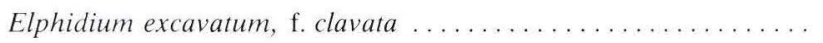 & 189 & 57 \\
\hline 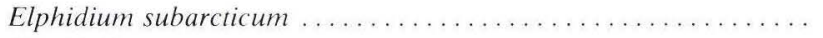 & 61 & 18 \\
\hline 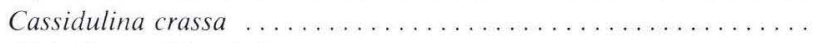 & 38 & 11 \\
\hline 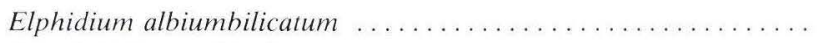 & 10 & 3 \\
\hline 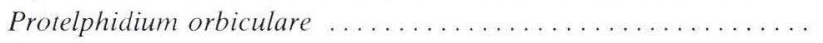 & 9 & 3 \\
\hline 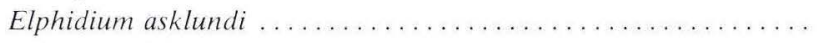 & 8 & 2 \\
\hline 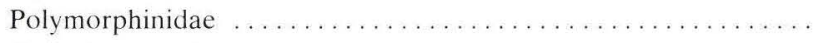 & 3 & 1 \\
\hline 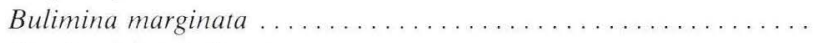 & 3 & 1 \\
\hline 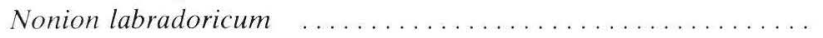 & 2 & 1 \\
\hline 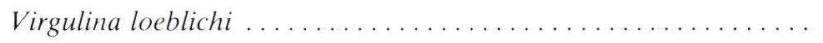 & 1 & $<1$ \\
\hline 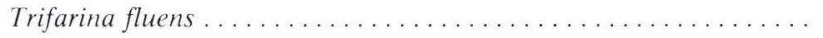 & 1 & $<1$ \\
\hline 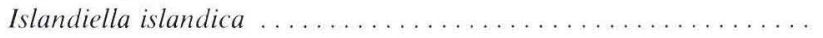 & 1 & $<1$ \\
\hline 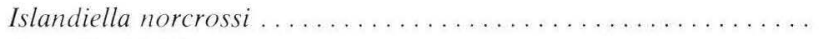 & 1 & $<1$ \\
\hline 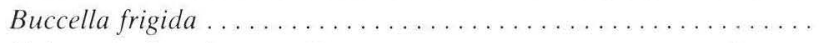 & 1 & $<1$ \\
\hline 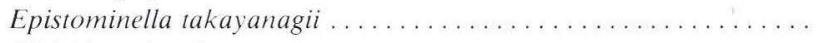 & 1 & $<1$ \\
\hline Elphidium bartletti . . . . . . . . . . . . . . . . . . . & 1 & $<1$ \\
\hline Elphidium magellanicum $\ldots \ldots \ldots \ldots \ldots \ldots \ldots \ldots \ldots \ldots$ & 1 & $<1$ \\
\hline
\end{tabular}

Total

The faunal diversity of the sample is 7 . The distribution of species is very close to those found in the E. subarcticum zone at Nørre Lyngby, and the present zone is inferred to correspond to the Lower Saxicava Sand of Vendsyssel. This deposit was described by Jessen in 1899 as the lower Late-glacial shore deposit and later, in 1918, 1931 and 1936 as the Lower Saxicava Sand.

At Nørre Lyngby this sandy facies occurs within the lower part of the clayey E. excavatum zone, whereas at Maarup the Lower Saxicava Sand rests directly upon a till, which is probably marine in its upper part. However, according to Jessen (1931) the Lower Saxicava Sand at Maarup, which is up to about 16-18 m thick, also contains some clayey layers in the lower part of the section.

A radiocarbon date of shells (Hiatella arctica (Linné)) from the Lower 
Saxicava Sand at Maarup gave an age of 13,900 \pm 220 B.P. (Tauber 1966 a, b, Krog \& Tauber 1974). Radiocarbon dates from marine deposits at Nørre Lyngby and from other localities in Vendsyssel are summarized in table 1:

Table 1. Radiocarbon dates from marine Late-glacial deposits at Nørre Lyngby (this paper) and other localities in Vendsyssel (Krog \& Tauber 1974).

Nørre Lyngby Other localities in

Vendsyssel

Zirfaea Beds

$11,950 \pm 190-12,770 \pm 190$ B.P.

Upper Saxicava Sand

(?) $14,310 \pm 180$ B.P.

Younger Yoldia Clay $\quad 14,270 \pm 180$ B.P.

Boundary Y. Yol. C./L. Sax. S. $\quad 14,650 \pm 190$ B.P.

Lower Saxicava Sand

$12,650 \pm 180-14,280 \pm 240$ B.P.

$13,900 \pm 220$ B.P.

A sediment layer of about $30 \mathrm{~cm}$ in profile 4 comprising the upper part of the E. subarctium zone and the lower part of the overlying clay (the E. excavatum zone) was rich in mollusc shells, all belonging to one species, Hiatella arctica, and most af them in their living position in the sediment. Shells from that

\begin{tabular}{|c|c|c|c|c|}
\hline STAGE & SUBSTAGE & $\begin{array}{l}\text { CHRONO- } \\
\text { ZONE }\end{array}$ & $\begin{array}{c}\text { FORAMINIFERAL } \\
\text { ZONES }\end{array}$ & $\begin{array}{c}\text { STRATIGRAPHIC } \\
\text { UNITS } \\
\text { (sensu Jessen) }\end{array}$ \\
\hline \multirow{7}{*}{ Weichselian } & \multirow{4}{*}{$\begin{array}{c}\text { Late } \\
\text { Weichselian }\end{array}$} & Younger Dryas & & \\
\hline & & Allerød & & \\
\hline & & Older Dryas & & \\
\hline & & Bølling & $\begin{array}{c}\text { Elphidium } \\
\text { albiumbilicatum } \\
\text { zone }\end{array}$ & Upper Saxicava Sand \\
\hline & \multirow{3}{*}{$\begin{array}{c}\text { Middle } \\
\text { Weichselian }\end{array}$} & & $\begin{array}{c}\text { E. excavatum zone } \\
\text { with } \\
\text { E. subarcticum zone }\end{array}$ & $\begin{array}{l}\text { Younger Yoldia Clay } \\
\text { with } \\
\text { Lower Saxicava Sand }\end{array}$ \\
\hline & & & & \\
\hline & & $\begin{array}{ll}\text { us } & \text { Denekamp } \\
\text { c } & \\
\text { c } & \text { Hengelo } \\
\text { o } & \text { Hent }\end{array}$ & $\begin{array}{c}\text { Bulimina marginata } \\
\text { - Buccella frigida } \\
\text { zone }\end{array}$ & Older Yoldia Clay \\
\hline
\end{tabular}

Fig. 10. Stratigraphic correlations of foraminiferal zones and stratigraphic units (sensu Jessen $1918,1936)$ in the Nørre Lyngby area. Chronostratigraphic subdivisions after Mangerud et al. (1974). 
level were collected for radiocarbon dating, and yielded the age of 14,650 \pm 190 B.P. (K-2670). The similarity of both foraminiferal faunas and radiocarbon ages justifies a correlation of the E. subarcticum zone at Nørre Lyngby with the Lower Saxicava Sand at Maarup. They may not be of exactly equal age, but corresponding marine ecological conditions must have prevailed during their deposition. Lower Saxicava Sand has not previously been recognized at Nørre Lyngby.

The Lower Saxicava Sand of Vendsyssel has earlier been correlated with pollen zone I a (Oldest Dryas) by S. Hansen (1965), Iversen (1967, 1973), Krog (1968) and Feyling-Hanssen et al. (1971). According to the chronostratigraphic subdivision of the Weichselian proposed by Mangerud et al. (1974), the present deposit belongs in the later part of the Middle Weichselian (fig. 10). Radiocarbon dates from the Lower Saxicava Sand infer that this shallow water facies may have been deposited during a lowering in sea level of about $10 \mathrm{~m}$ described by Mörner $(1969,1971)$. He suggested this to have taken place from about 15,000 B.P. until about 13,750 B.P. with minor oscillation, and correlated it with a temporary but distinct and worldwide climatic deterioration (Mörner 1973).

\section{The Elphidium excavatum zone}

The foraminiferal faunas of the Elphidium excavatum zone are similar to those described from the Younger Yoldia Clay elsewhere in Vendsyssel (Jørgensen 1971, Knudsen 1971) and the present assemblage zone is correlated with that deposit. Jessen $(1899,1918,1931,1936)$ and Jessen \& Nordmann (1915) described this stratigraphic unit as the Late-glacial Yoldia Clay, but later it was called the Younger Yoldia Clay to distingusih it from the Weichselian interstadial and stadial Older Yoldia Clay of Vendsyssel (Feyling-Hanssen et al. 1971).

Two radiocarbon dates were obtained on shells from the E. excavatum zone at Nørre Lyngby. Besides the date mentioned above from the lowermost part of the clay and the underlying sand in profile 4 (14,650 \pm 190 B.P.) shells of Hiatella arctica from a higher level in the zone about $200 \mathrm{~m}$ north of profile 4 (collected by N. Abrahamsen) were dated at 14,270 \pm 180 B.P. (K-2671) (see also table 1, p. 28). The Younger Yoldia Clay of Vendsyssel was earlier dated at 12,650 \pm 180 B.P. - 14,280 \pm 240 B.P. (Tauber 1966 a, b, Krog \& Tauber 1974). Together with the Lower Saxicava Sand this deposit has also been correlated with pollen zone I a (Oldest Dryas) (S. Hansen 1965, Iversen 1967, 1973, Krog 1968, Feyling-Hanssen et al. 1971).

As the boundaries for pollen zone I a are difficult to define, van der Hammen (1957) and van der Hammen \& Vogel (1966) suggested the Oldest Dryas to be included in the Bølling interstadial (sensu lato), which accord- 
ingly represents the beginning of Late-glacial time. Its lower boundary was suggested to be about 13,300 B.P. (van der Hammen 1957). In 1974 Mangerud et al. followed that suggestion, proposing the lower boundary for Bølling s.l. to be defined at 13,000 B.P. According to this chronostratigraphic subdivision a major part of the Younger Yoldia Clay (E. excavatum zone) of Vendsyssel belongs in late Middle Weichselian time, but at least in some places the deposition of clay continued into the Late Weichselian Bølling interstadial (fig. 10).

\section{The Elphidium albiumbilicatum zone}

The sandy sequence, the Elphidium albiumbilicatum zone, which in many places overlies the E. excavatum zone (Younger Yoldia Clay) corresponds to the deposit described by Jessen in 1899 as the upper Late-glacial shore deposit, and later, in 1918, 1931 and 1936, as the Upper Saxicava Sand.

A radiocarbon date on shells (Hiatella arctica) from the E. albiumbilicatum zone (Upper Saxicava Sand) of profile 2 in the coastal cliff at Nørre Lyngby yielded an age of $14,310 \pm 180$ B.P. (K-2413). The material was, however, rather unsuitable for dating as it consisted of weathered valves and fragments of Hiatella arctica, which may have been reworked from older deposits. This date thus gives only a maximum age for the deposit. Elsewhere in Vendsyssel shells from the Upper Saxicava Sand for radiocarbon dating were not found. Usually this deposit has earlier been correlated with the upper part of pollen zone I a (Oldest Dryas) (S. Hansen 1965, Iversen 1967, 1973, Krog 1968, Feyling-Hanssen et al. 1971).

Beach deposits with boreo-arctic mollusc faunas from Borgbakke and Raaholt at Frederikshavn have previously been referred to the Upper Saxicava Sand by Jessen (1936). Radiocarbon dates of three samples from these deposits ranged from $12,020 \pm 180$ B.P. to $12,400 \pm 180$ B.P. (Krog \& Tauber 1974), which is within the age range of the Bølling interstadial (pollen zone I b). A correlation of these layers with the Zirfaea Beds of northwestern Vendsyssel has also previously been proprosed by Jessen (1899) and by Krog (1968). As mentioned above, Jessen later changed this interpretation.

Because of the rising temperature, which is indicated by the foraminiferal faunas in the E. albiumbilicatum zone (Upper Saxicava Sand) at Nørre Lyngby, it is suggested that this deposit may also belong in the Bølling interstadial. This might also be the case for other deposits of Upper Saxicava Sand in Vendsyssel. However, as the biostratigraphical boundary between the $E$. excavatum zone and the E. albiumbilicatum zone and the lithological change from clay to sand are presumably not synchronous, possibly only part of the Upper Saxicava Sand belongs in the Bølling interstadial (fig. 10). In connec- 
tion with this it should be mentioned that a peat layer in the freshwater deposits above the E. albiumbilicatum zone at Nørre Lyngby has been dated to between late Bølling and early Allerød time (Krog 1978). This peat was inferred by Krog to consist of redeposited material.

In order to compare the foraminiferal faunas of the E. albiumbilicatum zone (Upper Saxicava Sand) at Nørre Lyngby with faunas from radiocarbon dated marine sediments of Bølling interstadial age, samples from the Zirfaea Beds in northwestern Vendsyssel have been analysed. Shells from this mostly sandy deposit have been dated at $12,770 \pm 190$ B.P. to $11,950 \pm 190$ B.P. (Krog \& Tauber 1974) (see also table 1, p. 28). A sample from the Zirfaea Beds at Skeen Møllebæk contained the following foraminifera in one third of 100 g sediment (see also Knudsen 1977):

Skeen Møllebæk, Zirfaea Beds. Coll. Knudsen 1972.

\begin{tabular}{|c|c|c|}
\hline Species & Frequency & Percentage \\
\hline 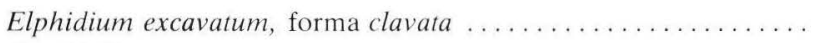 & 388 & 79 \\
\hline 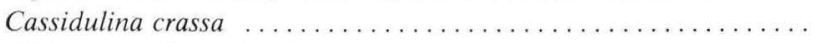 & 41 & 8 \\
\hline 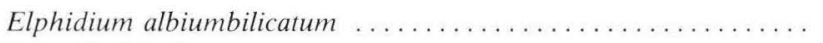 & 35 & 7 \\
\hline 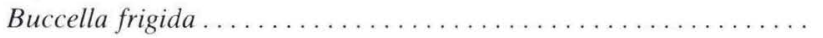 & 10 & 2 \\
\hline Elphidium subarcticum . . . . . . . . . . . . . . . . & 8 & 2 \\
\hline 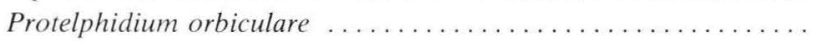 & 2 & $<1$ \\
\hline Lagena semilineata . . . . . . . . . . . . . . . . . . . & 1 & $<1$ \\
\hline 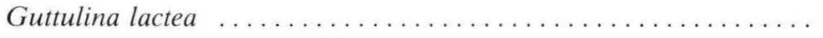 & 1 & $<1$ \\
\hline 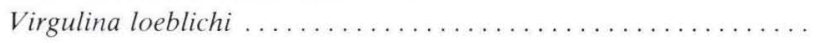 & 1 & $<1$ \\
\hline 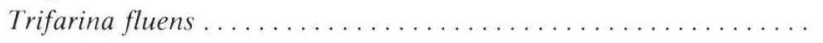 & 1 & $<1$ \\
\hline 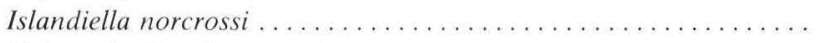 & 1 & $<1$ \\
\hline 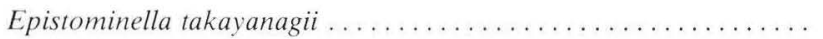 & 1 & $<1$ \\
\hline 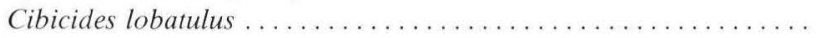 & 1 & $<1$ \\
\hline 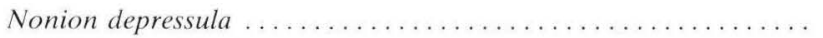 & 1 & $<1$ \\
\hline 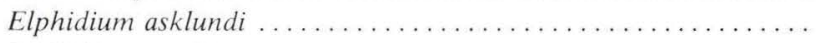 & 1 & $<1$ \\
\hline 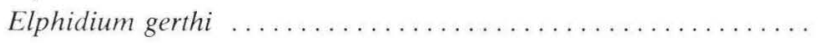 & 1 & $<1$ \\
\hline
\end{tabular}

Total.

494

Six other species were observed in the sample in addition to those listed above. The faunal diversity is 4 , and the number of specimens per $100 \mathrm{~g}$ sediment is about 1500 .

This foraminiferal fauna, which indicates increasing water temperature compared to the underlying arctic E. excavatum zone (Younger Yoldia Clay) faunas, is very much like those described above from the E. albiumbilicatum zone (Upper Saxucava Sand). The molluscan faunas are, however, different in the two deposits. The Zirfaea Beds contain a boreo-arctic mollusc fauna, whereas only a few specimens of one mollusc species, Hiatella arctica, were 
found in the Upper Saxicava Sand. This may, however, have been caused by local ecological differences which did not affect the foraminiferal faunas.

According to Jessen (1936) there are indications of a break in sedimentation in the outcrops at Skeen Møllebæk between the Younger Yoldia Clay below and the Zirfaea Beds above.

Krog \& Tauber (1974) demonstrated an age difference of 840 years between the uppermost part of the Younger Yoldia Clay and the lowermost part of the Zirfaea Beds. However, in a $31 \mathrm{~m}$ deep boring just south of Skeen Møllebæk (Knudsen in prep.) there seems to be a gradual transition from the Younger Yoldia Clay into a sandy deposit with foraminiferal faunas as found in the Zirfaea Beds. The change in faunal composition in this boring corresponds to that found in the sequences at Nørre Lyngby leading from the Younger Yoldia Clay into the Upper Saxicava Sand. Additional radiocarbon dates may contribute to solve these chronostratigraphical problems. 


\section{Foraminifera}

The foraminiferal species found in Middle and Late Weichselian deposits of the Nørre Lyngby area are arranged alphabetically in the following list, and selected species are illustrated in plates 1-5. For original references, synonymy lists, taxonomic remarks, and additional illustrations of the species mentioned in the present work, the reader is referred to the systematic section of Feyling-Hanssen et al., 1971. Only for later erected species, for additional species and when taxonomic problems makes it necessary, a few references have been added in the list.

In addition to the 72 listed species, there are some species belonging to the family Polymorphinidae, i.a. Guttulina austriaca d'Orbigny, 1846, G. lactea (Walker \& Jacob, 1798) and Pseudopolymorphina novangliae (Cushman, 1923). As the Polymorphinidae usually account for less than $1 \%$ of the fauna, they have been counted as a group in the present material, and the species are therefore not entered in the list.

The frequencies of the most common and characteristic species in the deposits are shown in range charts (figs. 4-9). Other species only occur scattered in the deposits, and usually they account for less than $1 \%$ of the faunas.

The figured specimens and faunas, Catalogue No. 1976-KLK-1 to 1976-KLK-39 and 1976-KLK-F1 to 1976-KLK-F4, are kept in the Department of Micropalaeontology, Geological Institute, University of Aarhus, DK-8000 Aarhus C, Denmark.

Ammonia batavus (Hofker, 1951). Pl. 3, fig. 11

Astrononion gallowayi Loeblich \& Tappan, 1953

Bolivina pseudoplicara Heron-Allen \& Earland, 1930

Bolivina cf. robusta Brady, 1884

Buccella frigida (Cushman, 1922). Pl. 1, figs. 15-16

Buccella tenerrima (Bandy, 1950)

Buccella wrightii (Brady, 1881)

1881: Discorbina wrightii Brady: Quart. f.

Micr. sci. 21, p. 413, pl. 21, fig. 6.
Bulimina fossa Cushman \& Parker, 1938

Bulimina marginata d'Orbigny, 1826. Pl. 1, figs. 2-3

Buliminella elegantissima (d'Orbigny, 1839)

Cassidulina crassa d'Orbigny, 1839. PI. 1, figs. $7-8$

Cassidulina laevigata d'Orbigny, 1826

Cibicides lobatulus (Walker \& Jacob, 1798)

Cibicides pseudoungerianus (Cushman, 1922)

Elphidium albiumbilicatum (Weiss, 1954).

Pl. 2, figs. 3-7; pl. 4, figs. $1-5$

Elphidium articulatum (d'Orbigny. 1839) 
1839: Polystomella articulata d'Orbigny: Voyage dans l'Amerique Méridionale Foraminifères. 5 (5). (Atlas 9, 1847). Paris, p. 30, pl. 3, figs. 9-10.

1971: Elphidium umbilicatulum (Williamson)

- Knudsen, in Feyling-Hanssen et al.: Bull. geol. Soc. Denmark 21, p. 281, pl. 13, figs. 8-11, pl. 23, figs. 1-4.

1977: Elphidium williamsoni Haynes Hansen \& Andersen: Fossils and Strata 10, p. 9-10, pl. 5, figs. 1-6.

Elphidium asklundi Brotzen, 1943. Pl. 2, figs. $8-9$; pl. 3 , fig. 1 ; pl. 4 , figs. 6-8

Elphidium bartletti Cushman, 1933. PI. 3, fig. 2

Elphidium excavatum (Terquem), forma clavata Cushman, 1930. Pl. 3, figs. 3-5; pl. 5, figs. 1-4

1930: Elphidium incertum (Williamson), var. clavatum Cushman: U. S. nat. Mus., Bull. 104, p. 20, pl. 7, fig. 10.

1972: Elphidium excavatum (Terquem) forma clavata Cushman - Feyling-Hanssen: Micropaleontology 18 (3), p. 339, pl. 1, figs. 1-9, pl. 2, figs. $1-9$.

Elphidium gerthi van Voorthuysen, 1957

Elphidium groenlandicum Cushman, 1933

Elphidium incertum (Williamson, 1858)

Elphidium macellum (Fichtel \& Moll, 1798)

Elphidium magellanicum Heron-Allen \& Earland, 1932

Elphidium margaritaceum Cushman, 1930

Elphidium subarcticum Cushman, 1944. Pl.

3, figs. 6-8; pl. 5, figs. 5-8

Elphidium ustulatum Todd, 1957

Eoeponidella laesoeensis Michelsen, 1967

Epistominella takayanagii Iwasa, 1955

Fissurina danica (Madsen, 1895)

Fissurina laevigata Reuss, 1850

Fissurina lucida (Williamson, 1848)

Fissurina marginata (Montagu, 1803)

Glandulina laevigata d'Orbigny, 1826

Hyalinea baltica (Schroeter, 1783). Pl. 1, figs. $17-18$

Islandiella helenae Feyling-Hanssen \&

Buzas, 1976. P1. 1, figs. 9-10

1976: Islandiella helenae Feyling-Hanssen \& Buzas: Journ. of Foram. Res. 6 (2), p. 156 , figs. 1-4.
Islandiella islandica (Nørvang, 1945). Pl. 1, figs. 11-12

Islandiella norcrossi (Cushman, 1933). PI. 1, figs. 13-14

Lagena laevis (Montagu, 1803)

Lagena semilineata Wright, 1886

Lagena striata (d'Orbigny, 1939), forma typica

Laryngosigma hyalascidia Loeblich \& Tappan, 1953

Laryngosigma williamsoni (Terquem, 1878)

Nonion barleeanum (Williamson, 1858)

Nonion depressula (Walker \& Jacob, 1798) 1978 Nautilius depressulus Walker \& Jacob in Adams, G.: Essays on the Microscope. Kanmacher, Ed. 2, London, p. 641, fig. 33 .

1965: Nonion depressulus (Walker \& Jacob) - Murray: Cushman Found. Foram. Res., Contr. 3 (4), p. 148 , pl. 25, figs. $6-7$, pl. 26 , figs. 7-8.

1971: Nonionumbilicatulum (Walker \&Jacob) - Knudsen, in Feyling-Hanssen et al.: Bull. geol. Soc. Denmark 21, p. 263, pl. 10, figs. 3-4, pl. 19, figs. 2-3.

Nonion labradoricum (Dawson, 1960). Pl. 2, figs. 1-2

Oolina acuticosta (Reuss, 1862)

Oolina borealis Loeblich \& Tappan, 1954

Oolina caudigera (Wiesner, 1931)

Oolina hexagona (Williamson, 1848)

Oolina lineata (Williamson, 1848)

Oolina melo d'Orbigny, 1839

Oolina williamsoni (Alcock, 1865)

Parafissurina lateralis (Cushman), forma simplex (Buchner, 1940)

Parafissurina tectulostoma Loeblich \& Tappan, 1953

Patellina corrugata Williamson, 1858

Pateoris hauerinoides (Rhumbler, 1936)

Protelphidium anglicum Murray, 1965

Protelphidium orbiculare (Brady, 1881). Pl.

3, figs. 9-10

Pullenia bulloides (d'Orbigny, 1826)

Pullenia subcarinata (d'Orbigny, 1839)

Pyrgo williamsoni (Silvestri, 1858)

Quinqueloculina agglutinata Cushman, 1917

Quinqueloculina seminulum (Linné, 1758).

Pl. 1, fig. 1 
Quinqueloculina stalkeri Loeblich \& Tappan, 1953

Textularia sagitulla Defrance, 1824

1824: Textularia sagittula Defrance: Dict. des Sci. Nat. 32, p. 177.

Trifarina angulosa (Williamson, 1858)

Trifarina fluens (Todd, 1947). Pl. 1, fig. 6
Uvigerina peregrina Cushman, 1923. PI. 1, fig. 5

Virgulina fusiformis (Williamson, 1858)

Virgulina loeblichi Feyling-Hanssen, 1954. Pl. 1, fig. 4

Virgulina schreibersiana Czjzek, 1848 


\section{Conclusions}

After deglaciation of the Nørre Lyngby region in the later part of the Middle Weichselian the lower areas were transgressed by the so-called Yoldia Sea. The substratum of this Late-glacial marine transgression was partly glaciofluvial sand and clay and partly a marine deposit, which is here called the Bulimina marginata-Buccella frigida zone. Based on the foraminiferal content and the stratigraphic position in the cliff section and borings, this assemblage zone is inferred to represent the upper part of the Older Yoldia Clay of Vendsyssel, i.e. of Middle Weichselian interstadial age.

The marine Late-glacial deposits in the Nørre Lyngby area are divided in three foraminiferal assemblage zones, the Elphidium subarcticum zone, which is correlated with the Lower Saxicava Sand, the E. excavatum zone, which is correlated with the Younger Yoldia Clay and the E. albiumbilicatum zone, which is correlated with the Upper Saxicava Sand of Vendsyssel. Elphidium excavatum, forma clavata is the dominant form in all three zones, but in the E. excavatum zone, there are especially high frequencies of this form. The E. subarcticum zone is characterised by high frequencies of E. subarcticum together with other species of Elphidium, whereas the E. albiumbilicatum zone is characterized by a high content of E. albiumbilicatum in addition to increases of other species. The foraminiferal faunas of the E. subarcticum zone (Lower Saxicava Sand) and the E. excavatum zone (Younger Yoldia Clay) are mainly arctic, whereas the E. albiumbilicatum zone (Upper Saxica$v a$ Sand) faunas are considered to be boreo-arctic.

Based on radiocarbon dates (table 1, p. 28) the E. subarctium zone and a major part of the E. excavatum zone are suggested to belong in late Middle Weichselian. The influence of boreal foraminiferal species in the E. albiumbilicatum zone infers that this zone might be of Late Weichselian Bølling interstadial age (fig. 10).

In the Nørre Lyngby area the E. subarcticum zone, or the Lower Saxicava Sand, occurs as an only $1.5 \mathrm{~m}$ thick sandy facies within the lower part of the E. excavatum zone (Younger Yoldia Clay).

The E. excavatum zone, or the Younger Yoldia Clay, has a thickness of up to more than $15 \mathrm{~m}$ and is found as nearly horizontally stratified deposits in the southern part of the cliff section. In some places this clay is overlain by a 
sandy deposit of variable thickness, the E. albiumbilicatum zone, or the Upper Saxicava Sand. The foraminiferal faunas indicate decreasing water depth during deposition of this uppermost marine zone. Isostatic adjustments after deglaciation caused the present areas to emerge above sea level.

Farther north in the cliff section the surface of the marine deposits forms a depression, which is filled with Late-glacial freshwater deposits. Beneath the central part of this basin the E. albiumbilicatum zone has a thickness of at least $14 \mathrm{~m}$, whereas about $100 \mathrm{~m}$ south of the centre it is only $2 \mathrm{~m}$ thick. Borings show that this depression can be followed from the cliff section inland towards east, and that about a similar succession of strata in the marine deposits is found in that direction.

This east-west trending depression may represent a deep valley formed prior to the Late-glacial transgression, either by the ice itself, or by meltwater streams during deglaciation, or a combination of these factors. However, the dip of the layers and the rapid increase in thickness of the E. albiumbilicatum zone towards the central part of the depression indicate continuous sinking of the basin during deposition. According to H. Lykke Andersen (pers. com.) seismic measurements in the area show a fault line in the chalk below the Nørre Lyngby depression. This fault might well have been active during the Quaternary, and may be the reason for continuous sinking of the basin during deposition of the present Middle and Late Weichselian (Bølling interstadial) deposits, and thus probably also for the slidings of the marine layers in the northern part of the basin. Another possible reason might have been gradual melting of buried ice in the area. 


\section{Acknowledgements}

I am grateful to Dr.philos. Rolf W. Feyling-Hanssen, Department of Micropalaeontology, Århus, Adjunkt Mogens Rehoff Hansen, Århus and Adjunkt Leif Christensen, Århus for valuable discussions during preparation of the present work. The borings were carried out by Svend Aa. Meldgaard and Ken Geer assisted by students, and Svend Aa. Meldgaard treated most of the samples in the laboratory and prepared the photographs. The drawings were made by Jette Gissel Nielsen, the scanning electron micrographs were prepared by Ulla Nielsen and J. Fuglsang Nielsen, Institute of Historical Geology and Palaeontology, University of Copenhagen, and the manuscript was typed by Lissi $\varnothing$. Mogensen. The radiocarbon dates were determined by Dr.phil. H. Tauber at the C-14 Dating Laboratory of the Geological Survey and the National Museum. My most sincere thanks are due to all these helpers. I also wish to thank Dr.philos. Rolf W. Feyling-Hanssen for reading the manuscript critically and Professor Jere H. Lipps, University of California, Davis, California and Dr. Richard Wilson, Århus for correcting the English of my manuscript. Finally I express my gratitude to the Danish Natural Science Research Council for financial support of the present investigation. 


\section{Dansk sammendrag}

Midt og sen Weichselien marine aflejringer ved Nørre Lyngby, Nordjylland, Danmark, og deres foraminifer-faunaer.

I kystklinten ved Nørre Lyngby i Vendsyssel ses et snit gennem marine, glaciofluviale og limniske Pleistocæne aflejringer. Der er foretaget kvantitative analyser af fossile benthoniske foraminiferfaunaer i de marine sedimenter dels fra kystklinten og boringer i stranden ved klintens fod og dels fra en serie boringer i området øst for klinten. De undersøgte marine aflejringer er på grundlag af foraminiferindholdet inddelt i fire faunazoner.

Den nederste zone indeholder en fauna, som domineres af de to arter Elphidium excavatum, forma clavata og Cassidulina crassa. Andre karakteristiske arter er Bulimina marginata, Islandiella norcrossi, Elphidium albiumbilicatum og Buccella frigida, og zonen er her kaldt Bulimina marginata-Buccella frigida zonen. Faunaen er arktisk med et indhold af enkelte mere varmekrævende arter, og zonen synes at kunne korreleres med den øvre del af det Ældre Yoldia Ler i Vendsyssel, som er henført til Sandnes interstadialen af midt Weichselien alder. B. marginata-B. frigida zonens sedimenter består hovedsagelig af leret silt eller finsand. Aflejringen forekommer dels i den nordlige del af kystklinten ved Nørre Lyngby, dels i den dybeste del af boring III samt i flere boringer i den nordlige og østlige del af det undersøgte område (fig. 2 og 3 ).

I store dele af Nørre Lyngby området er $B$. marginata- $B$. frigida zonens aflejringer, og visse steder også de glaciofluviale aflejringer, overlejret af marine Sen-glaciale aflejringer. Denne marine serie er inddelt i tre faunazoner på grundlag af foraminiferer, Elphidium subarcticum zonen, E. excavatum zonen og øverst E. albiumbilicatum zonen. Elphidium excavatum, forma clavata er en dominerende form i alle disse zoner, men faunaen i E. excavatum zonen er specielt karakteriseret af en meget høj dominans af denne form. E. subarcticum zonen er karakteriseret af en ret stor hyppighed af E. subarcticum sammen med E. asklundi, E. albiumbilicatum og Protelphidium orbiculare. E. albiumbilicatum zonen er karakteriseret dels af E. albiumbilicatum, dels af stigende frekvens af Cassidulina crassa, Bulimina marginata og en del andre arter, som ikke er almindelige i E. excavatum zonen.

Faunaerne i E. subarcticum zonen og i E. excavatum zonen er hovedsagelig arktiske, og disse zoner er korreleret med henholdsvis Nedre Saxicava Sand og Yngre Yoldia Ler i Vendsyssel. Faunaen i E. albiumbilicatum zonen er 
tolket som boreo-arktisk, og denne zone er korreleret med Øvre Saxicava Sand. Det skal nævnes, at en detaljeret undersøgelse af foraminiferfaunaerne gennem E. excavatum zonens sedimenter synes at afspejle en gradvis stigende temperatur og måske samtidig en lavere saltholdighed allerede under aflejringen af disse.

E. subarcticum zonen (Nedre Saxicava Sand) er kun fundet på to lokaliteter ved Nørre Lyngby. Den forekommer som en 1,5 m tyk, sandet facies inden for den allernederste del af E. excavatum zonen (Yngre Yoldia Ler). E. excavatum zonen forekommer i næsten hele klintens udstrækning ved Nørre Lyngby, i den sydlige del som en nogenlunde horisontalt lagdelt ler af op til mere end $15 \mathrm{~m}$ tykkelse. Visse steder overlejres den konkordant af en sandet lagserie, E. albiumbilicatum zonen (Øvre Saxicava Sand). Overfladen af den marine lagserie danner i den nordlige del af klinten en bassinformet depression af omkring $200 \mathrm{~m}$ udstrækning og indtil ca. $15 \mathrm{~m}$ dybde. Denne depression er fyldt med en Sen-glacial ferskvands-lagserie. I kystklinten nord for bassinet forekommer $E$. excavatum zonen og $E$. albiumbilicatum zonen atter i et højt niveau. De overlejrer her dels glaciofluviale sedimenter og dels B. marginata- $B$. frigida zonens aflejringer. Langs nordflanken af bassinstrukturen er de marine aflejringer forstyrrede på grund af senere udskridninger i bassinet.

Der er en stærkt tiltagende tykkelse af den øverste marine zone, Elphidium albiumbilicatum zonen (Øvre Saxicava Sand), mod den centrale del af bassinet. Zonen er omkring $2 \mathrm{~m}$ tyk ved bassinets sydlige begrænsning (profil 2) og tiltager til mere end $14 \mathrm{~m}$ under den centrale del (boring I). Boringerne øst for klinten viser, at nogenlunde det samme aflejringsmønster kan følges gennem en depression, som strækker sig i øst-vestlig retning.

Selve bassinstrukturen og den stærkt tiltagende lagtykkelse af den øverste marine zone mod den centrale del, synes at pege i retning af en kontinuerlig indsynkning af bassinet samtidig med aflejringen af E. albiumbilicatum zonens sedimenter. Dannelsen af dette bassin samt forstyrrelserne i lagene langs nordflanken kan muligvis knyttes sammen med Kvartære bevægelser langs en forkastning, som ved hjælp af seismiske målinger er registreret i kalken under Nørre Lyngby. En anden mulig årsag til bassindannelsen kan have været langsom bortsmeltning af dødis i området.

Der er foretaget én C-14 datering fra grænsen mellem E. subarcticum zonen (Nedre Saxicava Sand) og E. excavatum zonen (Yngre Yoldia Ler) og én fra et højere niveau i $E$. excavatum zonens aflejringer ved Nørre Lyngby.

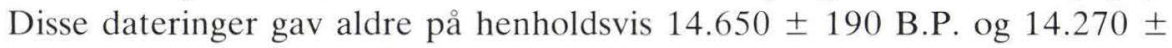
180 B.P. Andre steder i Vendsyssel er Yngre Yoldia Ler dateret til mellem $14.280 \pm 240$ B.P. og $12.650 \pm 180$ B.P. Ifølge den kronostratigrafiske inddeling, som er foreslået af Mangerud et al. (1974), synes således i hvert 
fald størstedelen af det Yngre Yoldia Ler i Vendsyssel at være af sen midt Weichselien alder (fig. 10).

Foruden ovennævnte datering fra grænsen mellem Nedre Saxicava Sand og Yngre Yoldia Ler, foreligger en enkelt datering af skaller fra Nedre Saxicava Sand (ved Maarup), som gav en alder på $13.900 \pm 220$ B. P. Dannelsen af denne sandede facies $\mathrm{i}$ den nedre del af E. excavatum zonen ved Nørre Lyngby kan muligvis sættes i forbindelse med en sænkning af havspejlet på omkring $10 \mathrm{~m}$, som menes at have fundet sted under en koldere periode fra omkring 15.000 B.P. frem til omkring 13.700 B.P.

Der foreligger kun en enkelt datering fra E. albiumbilicatum zonen (Øvre Saxicava Sand) ved Nørre Lyngby. Da skallerne muligvis kan være omlejrede er dateringen ret usikker. Den gav en alder på $14.310 \pm 180$ B.P. Der findes ingen C-14 dateringer fra sikkert Øvre Saxicava Sand andre steder i Vendsyssel. En sammenligning af foraminiferfaunaerne i E. albiumbilicatum zonen (Øvre Saxicava Sand) ved Nørre Lyngby med faunaer fra Zirfaea lagene ved Skeen Møllebæk, som er dateret til Bølling interstadial tid, viser, at der er meget stor lighed mellem disse. Bedre dateringer af det Øvre Saxicava Sand ville sandsynligvis vise, at denne aflejring, eller i hvert fald en del af den, også kan henregnes til Bølling interstadial tid. Da de lithologiske grænser mellem de marine Sen-glaciale zoner i Vendsyssel imidlertid må formodes at være diakrone, kan kun yderligere biostratigrafiske undersøgelser kombineret med en serie C-14 dateringer løse disse mere detaljerede stratigrafiske problemer.

På grund af samspillet mellem isostatiske og eustatiske bevægelser efter Weichselisens afsmeltning blev Nørre Lyngby området efter dannelsen af Øvre Saxicava Sand omdannet til et landområde. 


\section{References}

Abrahamsen, N. \& Knudsen, K. L. In press: Indication of a Geomagnetic Low-Inclination Excursion in supposed Middle Weichselian Interstadial Marine Clay at Rubjerg, Denmark. - Physics of the Earth and Planet. Inter., 18 (1979).

Andersen, A.-L. L. 1971: Foraminifera from the Older Yoldia Clay at Hirtshals. - In:

Feyling-Hanssen, R. W., Jørgensen, J. A., Knudsen, K. L. \& Andersen, A. - L. L. Late

Quaternary Foraminifera from Vendsyssel, Denmark and Sandnes, Norway. - Bull. geol. Soc. Denmark, 21, 2-3, pp. 159-184.

Bahnson, H., Petersen, K. S., Konradi, P. B. Knudsen, K. L. 1974: Stratigraphy of Quaternary deposits in the Skærumhede II boring: lithology, molluscs and foraminifera. - Danm. geol. Unders., Årbog 1973, pp. 27-62.

Cushman, J. A. 1944: Foraminifera from the shallow water of New England coast. Cushman Lab. Foram. Res., Spec. publ., 12, 37 p.

Feyling-Hanssen, R. W. 1958: Mikropaleontologiens teknikk. - Norges geol. Unders., 203, pp. $35-48$.

Feyling-Hanssen, R. W. 1966: Geologiske observasjoner i Sandnesområdet (Geological observations in the Sandnes area, Southwest Norway). - Norges geol. Unders., 242, pp. $26-43$.

Feyling-Hanssen, R. W. 1971: Weichselian interstadial Foraminifera from the Sandnes-Jæren area. - In: Feyling-Hanssen, R. W. Jørgensen, J. A., Knudsen, K. L., \& Andersen, A. L. L. Late Quaternary Foraminifera from Vendsyssel, Denmark and Sandnes, Norway. - Bull. geol. Soc. Denmark, 21, 2-3, pp. 72-116.

Feyling-Hanssen, R. W. 1974: The Weichselian section of Foss-Eigeland, Southwestern Norway. - Geol. Fören. Stockholm Förh., 96, pp. 341-353.

Feyling-Hanssen, R. W., Jørgensen, J. A., Knudsen, K. L. \& Andersen, A. - L. L. 1971: Late Quaternary Foraminifera from Vendsyssel, Denmark and Sandnes, Norway. Bull. geol. Soc. Denmark, 21, 2-3, pp. 67-317.

Hammen, T. van der 1957: The stratigraphy of the Lateglacial. - Geol. en Mijnb. (Nw.Ser.), 19 , pp. $250-254$.

Hammen, T. van der \& Vogel, J. C. 1966: The Susacá interstadial and the Subdivision of the Late Glacial. -Geol. en Mijnb., 45, pp. 33-35.

Hammen, T. van der, Wijmstra, T. A. \& Zagwijn, W. H. 1971: The floral record of the Late Cenozoic of Europe. - In: Turekian, K. K. (ed.): The Late Cenozoic Glacial Ages, pp. 392-424, Yale University Press, New Haven, London.

Hansen, S. 1965: The Quaternary of Denmark, In: Rankama, K. (editor). - The Geologic Systems. The Quaternary 1, pp. 1-90, Interscience publishers, New York.

Hedberg, H. D. (ed.) 1976: International stratigraphic guide. A guide to stratigraphic classification, terminology and procedure, $200 \mathrm{p}$. Wiley and Sons, New York.

Iversen, J. 1942: En pollenanalytisk Tidsfæstelse af Ferskvandslagene ved Nørre Lyngby. Meddr Dansk geol. Foren., 10, pp. 130-151. 
Iversen, J. 1967: Naturens udvikling siden sidste istid. - In: Danmarks Natur, 1, pp.

345-445, Politikens Forlag, København.

Iversen, J. 1973: The development of Denmark's nature since the last glacial. - Danm. geol. Unders., V række, 7-C, 126 p.

Jessen, A. 1899: Beskrivelse til Geologisk kort over Danmark. Kortbladene Skagen,

Hirsthals, Frederikshavn, Hjørring og Løkken. - Danm. geol. Unders., I række, 3, 368 p.

Jessen, A. 1918: Vendsyssels Geologi. - Danm. geol. Unders., V række, 2, 260 p.

Jessen, A. 1931: Lønstrup Klint. - Danm. geol. Unders., II række, 49, 142 p.

Jessen, A. 1936: Vendsyssels Geologi. Revised edition. - Danm. geol. Unders., V række, 2 , 195 p.

Jessen, A. \& Nordmann, V. 1915: Ferskvandslagene ved Nørre Lyngby. - Danm. geol. Unders., II række, 29, 66 p.

Johnstrup, F. 1882: Om de geologiske forhold i den nordlige Del af Vendsyssel. Universitetsfestskrift, København, 48 p.

Jørgensen, J. A. 1971: The Quaternary of Vendsyssel. - In: Feyling-Hanssen, R. W., Jørgensen, J. A., Knudsen, K. L. \& Andersen, A. - L. L. Late Quaternary Foraminifera from Vendsyssel, Denmark and Sandnes, Norway. - Bull. geol. Soc. Denmark, 21, 2-3, pp. 117-129.

Knudsen, K. L. 1971: Late Quaternary Foraminifera from the Løkken area. - In:

Feyling-Hanssen, R. W., Jørgensen, J. A., Knudsen, K. L. \& Andersen, A.-L. L. Late Quaternary Foraminifera from Vendsyssel, Denmark and Sandnes, Norway, - Bull. geol. Soc. Denmark, 21, 2-3, pp. 130-158.

Knudsen, K. L. 1973: Foraminifera from Postglacial deposits of the Lundergård area in Vendsyssel, Denmark. - Bull. geol. Soc. Denmark, 22, pp. 255-282.

Knudsen, K. L. 1976: Foraminifer faunas in Weichselian stadial and interstadial deposits of the Skærumhede boring, Jutland, Denmark. - Maritime Sediments, Spec. Publ., 1, B. Paleoecology and Biostratigraphy, Halifax, pp. 431-449.

Knudsen, K. L. 1977: Foraminiferal faunas of the Quaternary Hostrup Clay from northern Jutland, Denmark. - Boreas, 6, pp. 229-245.

Konradi, P. B. \& Knudsen, K. L. 1974: Foraminifera in the Skærumhede II boring. - In: Bahnson, H., Petersen, K. S., Konradi, P. B. \& Knudsen, K. L. Stratigraphy of Quaternary deposits in the Skærumhede II boring: lithology, molluses and foraminifera. - Danm. geol. Unders., Årbog 1973, pp. 43-57.

Krog, H. 1968: Late-glacial and Postglacial Shoreline displacement in Denmark. - In: Means of correlation of Quaternary successions, 8, Proc. VII. INQUA congress, pp. 421-435, University of Utah Press.

Krog, H. 1978: The Late Weichselian freshwater beds at Nørre Lyngby. C-14 dates and pollen diagram. - Danm. geol. Unders., Arbog 1976, pp. 29-43.

Krog, H. \& Tauber, H. 1974: C-14 chronology of Late- and Post-glacial marine deposits in North Jutland. - Danm. geol. Unders., Årbog 1973, pp. 93-105.

Lutze, G. F. 1965: Zur Foraminiferen-Fauna der Ostsee. - Meyniana 15, pp. 75-147.

Madsen, V. 1895: Istidens foraminiferer i Danmark og Holsten. - Meddr dansk geol. Foren., 2, pp. 1-229.

Mangerud, J., Andersen, S. T., Berglund, B. E. \& Donner, J. J. 1974: Quaternary stratigraphy of Norden, a proposal for terminology and classification. - Boreas, 3, pp. 109-128.

Michelsen, O. 1967: Foraminifera of the Late-Quaternary deposits of Læsø. - Meddr dansk geol. Foren., 17, pp. 205-263. 
Mörner, N. - A. 1969: The Late Quaternary history of the Kattegatt Sea and the Swedish West Coast. - Sveriges geol. Unders., Ser. C 640, 487 p.

Mörner, N. - A. 1971: Eustatic changes during the last 20,000 years and a method of separating the isostatic and eustatic factors in an uplifted area. - Palaeogeogr. Palaeoclim. Palaeoecol., 9, pp. 153-181.

Mörner, N. - A. 1973: Climatic changes during the last 35,000 years as indicated by land, sea and air data. - Boreas, 2, pp. 33-54.

Pingel, C. 1828: Om Diluviet og Alluviet i det nordlige Jylland. - Tidsskr. f. Naturvidensk., 5, pp. 121-144.

Tauber, H. 1966 a: Danske Kulstof-14 dateringsresultater II. - Meddr dansk geol. Foren., 16, pp. 153-176.

Tauber, H. 1966 b: Copenhagen radiocarbon dates VII. - Radiocarbon, 8, pp. 213-234.

Walton, W. R. 1964: Recent foraminiferal ecology and paleo-ecology. - In: Imbrie, J. \& Newell, N. D. (editors): Approaches to Paleoecology, pp. 151-237. Wiley and Sons, New York.

Weiss, L. 1954: Foraminifera and origin of the Gardiners Clay (Pleistocene), Eastern Long Island, New York. - U. S. geol. Surv., prof. Paper 254-G, pp. 139-163. 
Plates 
Plate 1

Miliolidae, Buliminidae, Cassidulinidae,

Catalogue No. Text page

Discorbidae, Anomalinidae

Fig. 1. Quinqueloculina seminulum (Linné, 1758)

Specimen from the E. subarcticum zone (Lower Saxicava Sand) of

bor. III, spl. no. 8, Nørre Lyngby; $\times 75 \ldots \ldots \ldots \ldots \ldots \ldots \ldots$ 1976-KLK-1

Figs. 2-3. Bulimina marginata d'Orbigny, $1826 \ldots \ldots \ldots \ldots \ldots \ldots$

Fig. 2. Specimen from the E. albiumbilicatum zone (Upper Saxica$v a$ Sand) of bor. III, spl. no. 27, Nørre Lyngby; $\times 75 \ldots \ldots \ldots$ Fig. 3. Specimen from the E. albiumbilicatum zone (Upper Saxica$v a$ Sand) of bor. III, spl. no. 26, Nørre Lyngby; $\times 75 \ldots \ldots \ldots$ 1976-KLK-3

Fig. 4. Virgulina loeblichi Feyling-Hanssen, 1954 ................ Specimen from the E. albiumbilicatum zone (Upper Saxicava Sand) of bor. IV, spl. no. 4, Nørre Lyngby; $\times 75$......... 1976-KLK-4

Fig. 5. Uvigerina peregrina Cushman, $1923 \ldots \ldots \ldots \ldots \ldots \ldots \ldots$ Specimen from the E. albiumbilicatum zone (Upper Saxicava Sand) of profile 1, spl. no. 5, Nørre Lyngby; $\times 75 \ldots \ldots \ldots$. 1976-KLK-5

Fig. 6. Trifarina fluens (Todd, 1947) ................... 35 Specimen from the E. albiumbilicatum zone (Upper Saxicava Sand) of bor. I, spl. no. 25, Nørre Lyngby; $\times 75 \ldots \ldots \ldots \ldots$ 1976-KLK-6

Figs. 7-8. Cassidulina crassa d'Orbigny, $1839 \ldots \ldots \ldots \ldots \ldots \ldots \ldots$. Specimen from the E. albiumbilicatum zone (Upper Saxicava Sand) of bor. III, spl. no. 25, Nørre Lyngby; × $75 \ldots \ldots \ldots$. . 1976-KLK-7

Figs. 9-10. Islandiella helenae Feyling-Hanssen \& Buzas, 1976 . . . . . Specimen from the E. albiumbilicatum zone (Upper Saxicava Sand) of profile 2, Nørre Lyngby; $\times 75 \ldots \ldots \ldots \ldots \ldots \ldots$ 1976-KLK-8

Figs. 11-12. Islandiella islandica (Nørvang, 1945) . . . . . . . . . 34 Specimen from E. excavatum zone (Younger Yoldia Clay) of bor. III, spl. no. 18, Nørre Lyngby; $\times 75 \ldots \ldots \ldots \ldots \ldots \ldots \ldots$ 1976-KLK-9

Figs. 13-14. Islandiella norcrossi (Cushman, 1933) .............. Specimen from the E. subarcticum zone (Lower Saxicava Sand) of bor. III, spl. no. 8 , Nørre Lyngby; $\times 75 \ldots \ldots \ldots \ldots \ldots \ldots$ 1976-KLK-10

Figs. 15-16. Buccella frigida (Cushman, 1922) . ............... Specimen from the E. albiumbilicatum zone (Upper Saxicava Sand) of bor. IV, spl. no. 1, Nørre Lyngby; $\times 75$......... 1976-KLK-11

Figs. 17-18. Hyalinea baltica (Schroeter, 1783) ................ Specimen from the $E$. albiumbilicatum zone (Upper Saxicava Sand) of bor. I, spl. no. 1, Nørre Lyngby; $\times 75$ 1976-KLK-12 


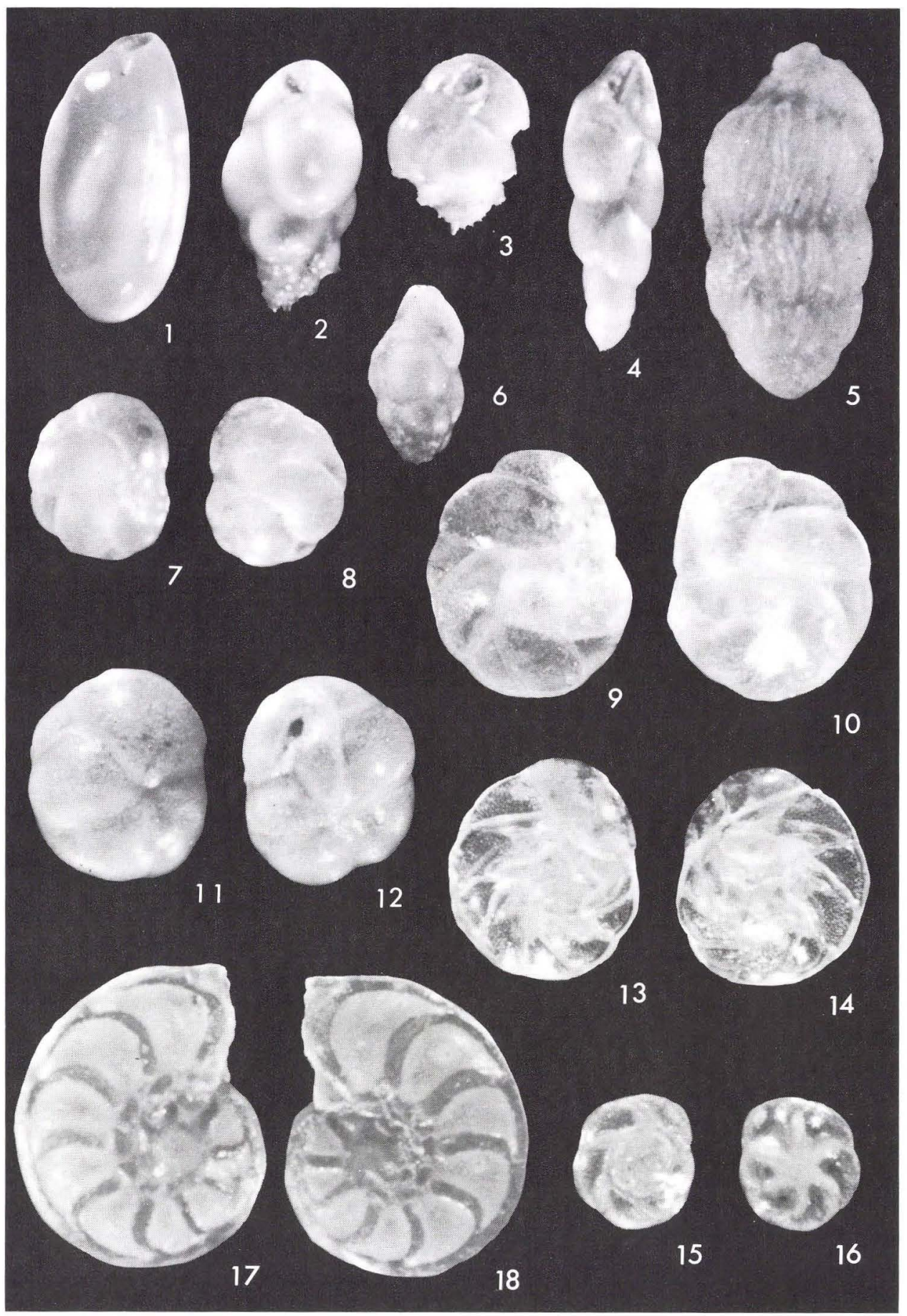




\section{Plate 2}

Nonionidae, Elphidiidae

Figs. 1-2. Nonion Labradoricum (Dawson, 1960)

Specimen from the E. albiumbilicatum zone (Upper Saxicava

Sand) of bor. III, spl. no. 31, Nørre Lyngby; × 75 ......... 1976-KLK-13

Figs. 3-7. Elphidium albiumbilicatum (Weiss, 1954)

Figs. 3-4. Specimen from the E. albiumbilicatum zone (Upper Saxicava Sand) of profile 2, Nørre Lyngby; $\times 75 \ldots \ldots \ldots \ldots$ 1976-KLK-14 Fig. 5. Specimen from the E. albiumbilicatum zone (Upper Saxica$v a$ Sand) of bor. IV, spl. no. 3, Nørre Lyngby; × $75 \ldots \ldots \ldots$ 1976-KLK-15 Fig. 6. Specimen from the E. albiumbilicatum zone (Upper Saxica$v a$ Sand) of profile 2, Nørre Lyngby; $\times 75 \ldots \ldots \ldots \ldots \ldots$ 1976-KLK-16 Fig. 7. Specimen from the E. albiumbilicatum zone (Upper Saxicava Sand) of bor. IV, spl. no. 3, Nørre Lyngby; $\times 75 \ldots \ldots \ldots \ldots$ 1976-KLK-17

Figs. 8-9. Elphidium asklundi Brotzen, $1943 \ldots \ldots \ldots \ldots \ldots \ldots$ Fig. 8. Specimen from the E. albiumbilicatum zone (Upper Saxicava Sand) of profile 2, Nørre Lyngby; $\times 75$............. 1976-KLK-18 Fig. 9. Specimen from the E. albiumbilicatum zone (Upper Saxicava Sand) of profile 1, spl. no. 3, Nørre Lyngby; × 75 ........ 1976-KLK-19 


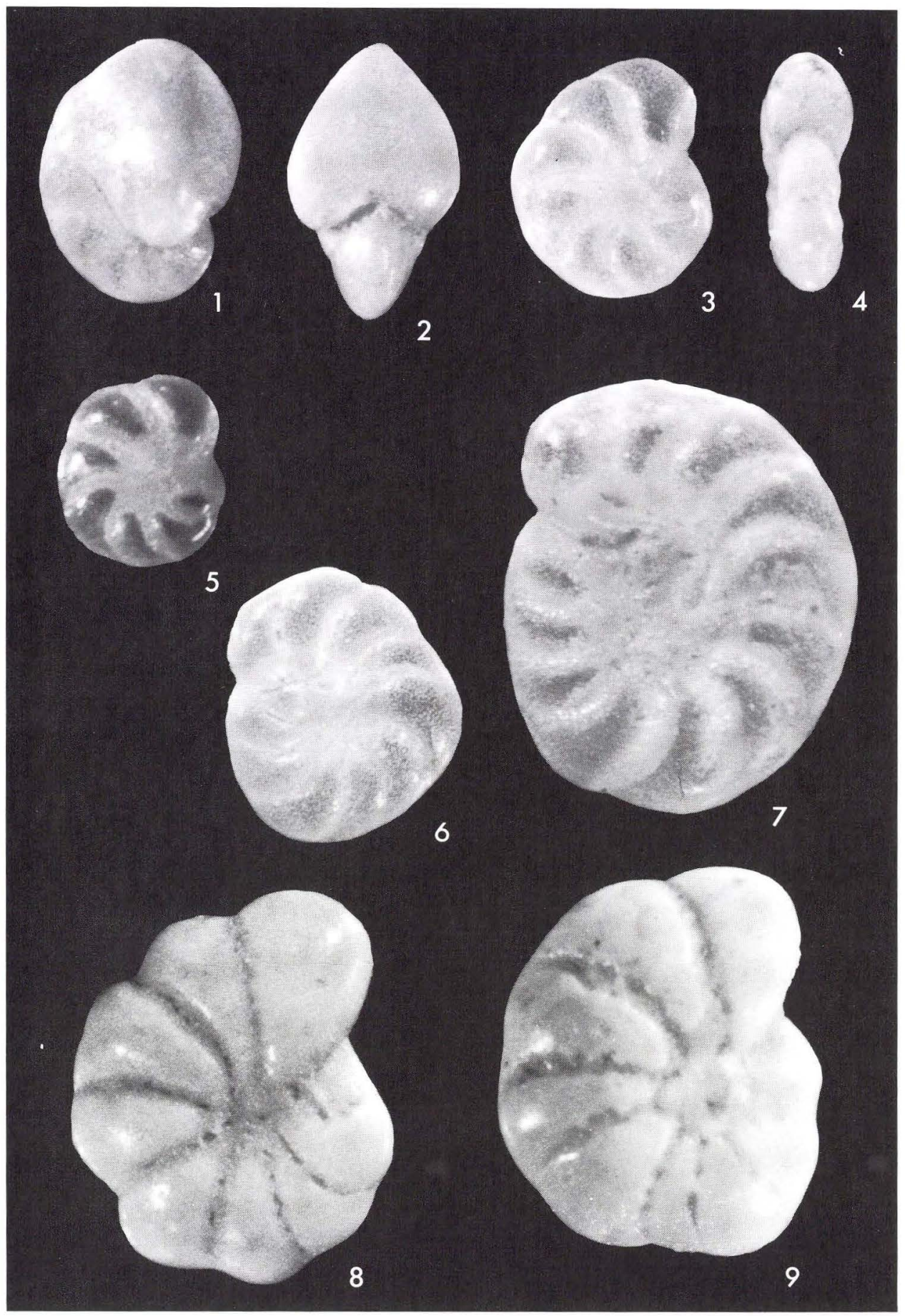


Plate 3

Elphidiidae, Rotaliidae

Catalogue No. Text page

Fig. 1. Elphidium asklundi Brotzen, $1943 \ldots \ldots \ldots \ldots \ldots \ldots \ldots$

Specimen from the E. albiumbilicatum zone (Upper Saxicava

Sand) of bor. IV, spl. no. 3, Nørre Lyngby; $\times 75$.......... 1976-KLK-20

Fig. 2. Elphidium bartletti Cushman, $1933 \ldots \ldots \ldots \ldots \ldots \ldots \ldots$

Specimen from the E. albiumbilicatum zone (Upper Saxicava

Sand) of bor. I, spl. no. 24, Nørre Lyngby; $\times 75 \ldots \ldots \ldots \ldots$. . . $1976-K L K-21$

Figs. 3-5. Elphidium excavatum (Terquem), forma clavata Cushman,

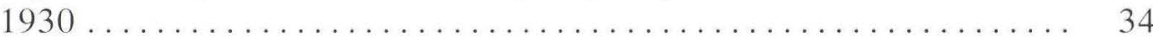

Fig. 3. Specimen from the E. albiumbilicatum zone (Upper Saxica$v a$ Sand) of bor. IV, spl. no. 5, Nørre Lyngby; $\times 75 \ldots \ldots \ldots$. . . 1976-KLK-22 Fig. 4. Specimen from the E. albiumbilicatum zone (Upper Saxica$v a$ Sand) of bor. IV, spl. no. 5, Nørre Lyngby; $\times 75 \ldots \ldots \ldots$ 1976-KLK-23 Fig. 5. Specimen from the E. albiumbilicatum zone (Upper Saxicava Sand) of bor. IV, spl. no. 5, Nørre Lyngby; × 75 ........ 1976-KLK-24

Figs. 6-8. Elphidium subarcticum Cushman, 1944 .............

Fig. 6. Specimen from the E. albiumbilicatum zone (Upper Saxicava Sand) of bor. IV, spl. no. 3, Nørre Lyngby; × 75 ......... 1976-KLK-25 Fig. 7. Specimen from the E. albiumbilicatum zone (Upper Saxicava Sand) c. $10 \mathrm{~m}$ north of profile 2, Nørre Lyngby; $\times 75$.... 1976-KLK-26 Fig. 8. Specimen from the E. albiumbilicatum zone (Upper Saxica$v a$ Sand) of bor. IV, spl. no. 5, Nørre Lyngby; $\times 75 \ldots \ldots \ldots$ 1976-KLK-27

Figs. 9-10. Protelphidium orbiculare (Brady, 1881) .......... 34

Specimen from the E. subarcticum zone (Lower Saxicava Sand) of bor. III, spl. no. 8, Nørre Lyngby; $\times 75 \ldots \ldots \ldots \ldots \ldots \ldots \ldots$ 1976-KLK-28

Fig. 11. Ammonia batavus (Hofker, 1951) . . . . . . . . . . . . . Spiral side of specimen from the E. albiumbilicatum zone (Upper Saxicava Sand) of bor. I, spl. no. 7, Nørre Lyngby; $\times 75$.... 1976-KLK-29 


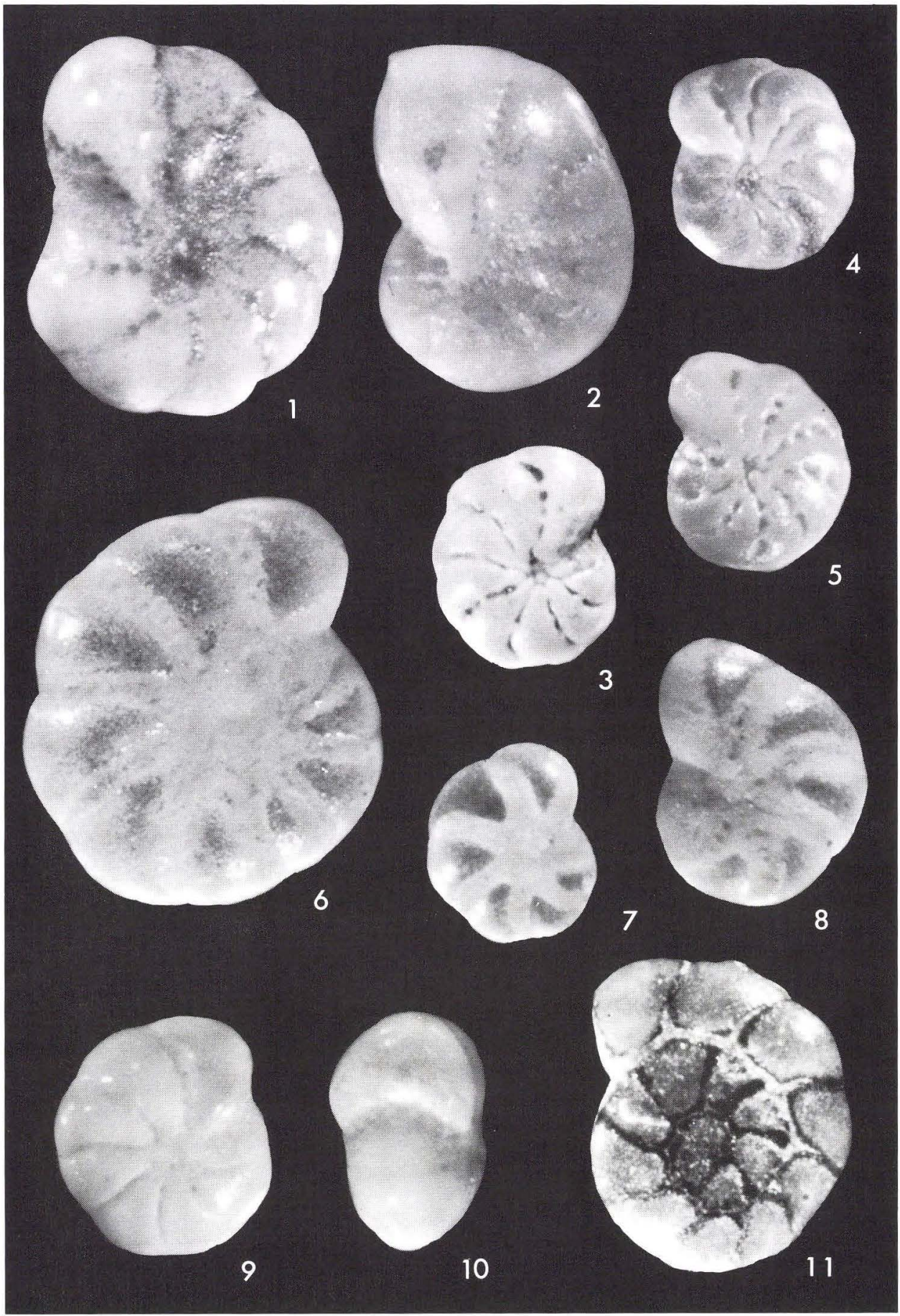


Plate 4

Elphidiidae

Catalogue No. Text page

Figs. 1-5. Elphidium albiumbilicatum (Weiss, 1954) .......... 33

Figs. 1-2. Specimen from the E. albiumbilicatum zone (Upper

Saxicava Sand) of bor. IV, spl. no. 2, Nørre Lyngby; $\times 160 \ldots$. 1976-KLK-30

Fig. 3. Specimen from the E. albiumbilicatum zone (Upper Saxica-

va Sand) of profile 2, Nørre Lyngby; $\times 100 \ldots \ldots \ldots \ldots \ldots$ 1976-KLK-31

Figs. 4-5. Specimen from the E. albiumbilicatum zone (Upper

Saxicava Sand) of profile 2, Nørre Lyngby; Fig. 4, × 100; Fig. 5, × 370

1976-KLK-32

Figs. 6-8. Elphidium asklundi Brotzen, 1943 . . . . . . . . . .

Fig. 6. Specimen from the E. excavatum zone (Younger Yoldia

Clay) of bor. III, spl. no. 12, Nørre Lyngby; $\times 70 \ldots \ldots \ldots \ldots .1976-K L K-33$

Figs. 7-8. Specimen from the E. excavatum zone (Younger Yoldia

Clay) of bor. IV, spl. no. 1 A, Nørre Lyngby; $\times 75$........ 1976-KLK-34

Scanning electron micrographs. 

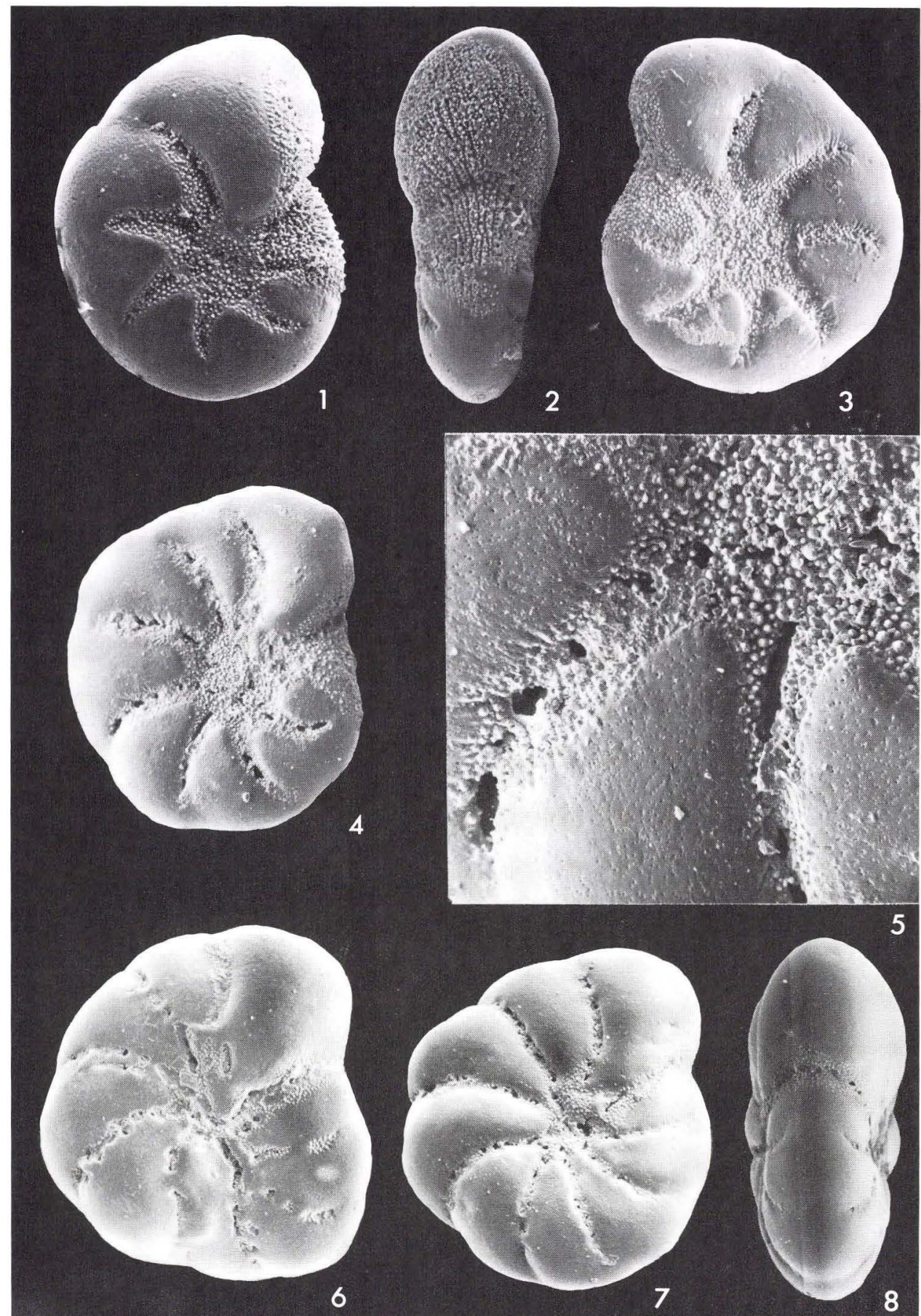

5 


\section{Plate 5}

Figs. 1-4. Elphidium excavatum (Terquem), forma clavata Cushman,

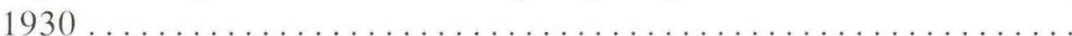

Fig. 1. Specimen from the E. excavatum zone (Younger Yoldia

Clay) of the coastal cliff at Norre Lyngby; $\times 110 \ldots \ldots$. . . . . 1976-KLK-35

Fig. 2. Edge view of specimen from the E. albiumbilicatum zone

(Upper Saxicava Sand) of bor. IV, spl. no. 4, Nørre Lyngby; × 135 1976-KLK-36

Fig. 3. Side view of the same specimen as Fig. $2 ; \times 120$

Fig. 4. Specimen from the E. albiumbilicatum zone (Upper Saxica-

va Sand) of bor. IV, spl. no. 2, Norre Lyngby; $\times 140 \ldots \ldots$. . 1976-KLK-37

Figs. 5-8. Elphidium subarcticum Cushman, 1944 ............. 34

Figs. 5-6. Specimen from the E. albiumbilicatum zone (Upper

Saxicava Sand) of bor. IV, spl. no. 2, Nørre Lyngby; × 80 ... 1976-KLK-38

Figs. 7-8. Specimen from the E. albiumbilicatum zone (Upper

Saxicava Sand) of bor. IV, spl. no. 2, Nørre Lyngby; Fig. 7, × 70;

Fig. $8, \times 180$

1976-KLK-39

Scanning electron micrographs. 


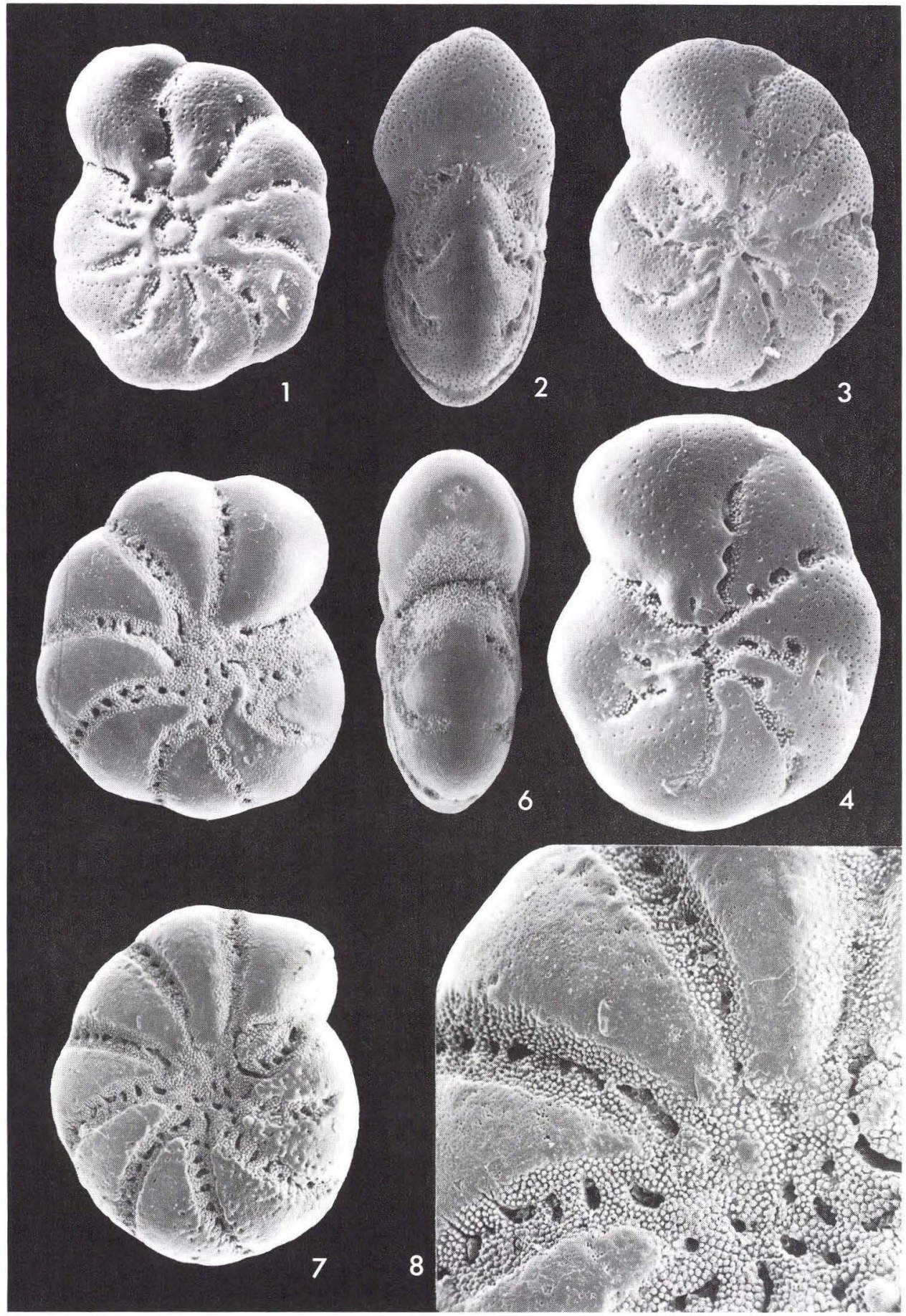


Plate 6

Catalogue No.

Fig. 1. Foraminiferal assemblage from the E. excavatum zone (Younger Yoldia Clay) of bor. III, spl. no. 18, Nørre Lyngby. The fauna is characterized by the very high dominance of Elphidium excavatum (Terquem), forma clavata Cushman; $\times 25$....... 1976-KLK-F1 Fig. 2. Foraminiferal assemblage from the E. subarcticum zone (Lower Saxicava Sand) of bor. III, spl. no. 8, Nørre Lyngby. Elphidium excavatum (Terquem), forma clavata Cushman is the dominant species, but the faunas in this sandy facies are characterized by the rather high frequencies of Elphidium subarcticum Cushman; $\times 25 \ldots \ldots \ldots \ldots \ldots \ldots \ldots \ldots \ldots \ldots \ldots \ldots \ldots \ldots \ldots \ldots \ldots$ 1976-KLK-F2 

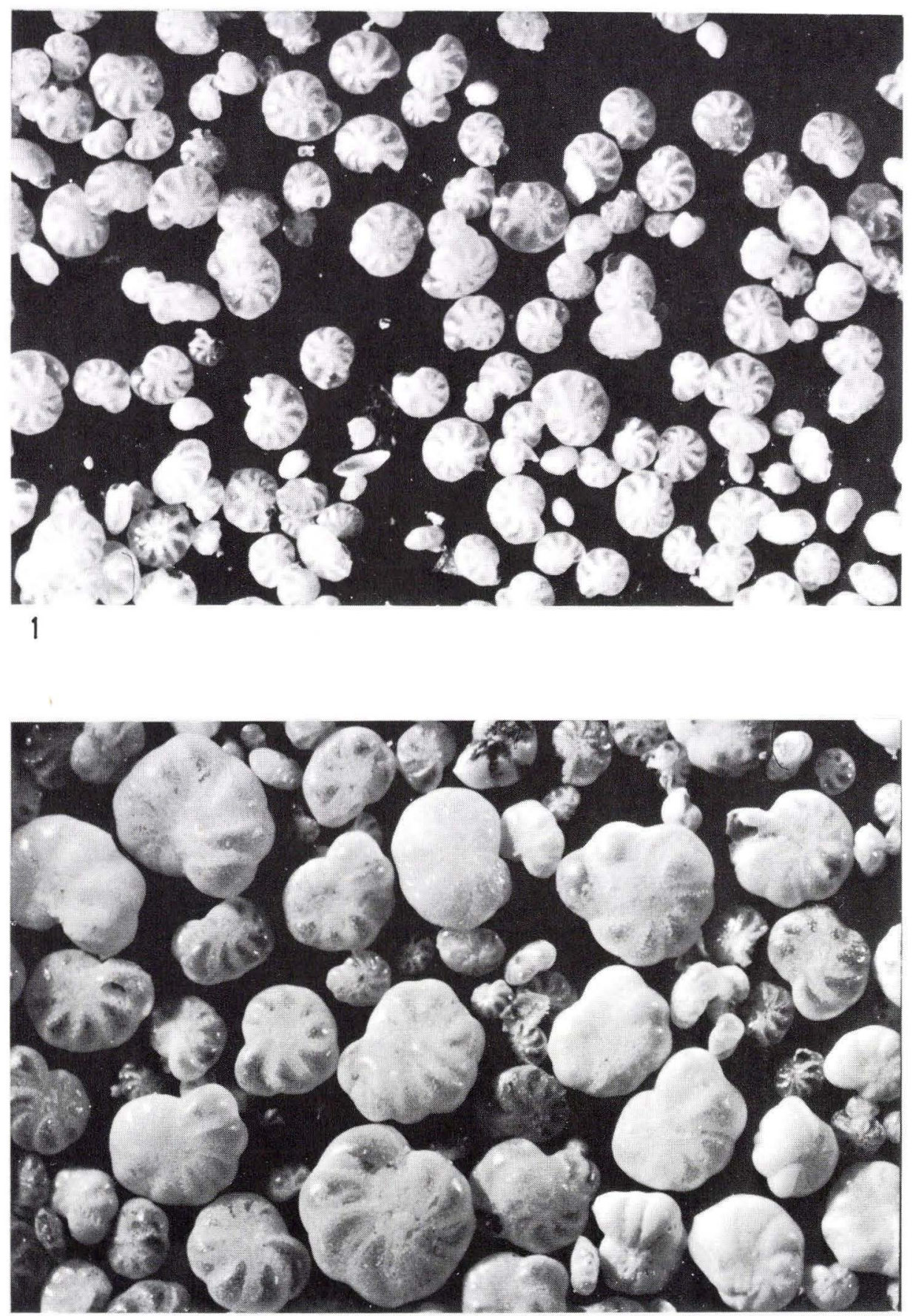


\section{Plate 7}

Catalogue No.

Fig. 1. Foraminiferal assemblage from the E. albiumbilicatum zone (Upper Saxicava Sand) of profile 2 in the coast cliff at Nørre Lyngby. Elphidium excavatum (Terquem), forma clavata Cushman is the dominant species, but the fauna is characterized by the high frequency of Elphidium albiumbilicatum (Weiss); $\times 25 \ldots \ldots$. . 1976-KLK-F3 Fig. 2. Foraminiferal assemblage from the E. albiumbilicatum zone (Upper Saxicava Sand) of bor. IV, spl. no. 3, Nørre Lyngby. The composition of species is very close to that of fig. $1 ; \times 25$.

$1976-\mathrm{KLK}-\mathrm{F} 4$ 

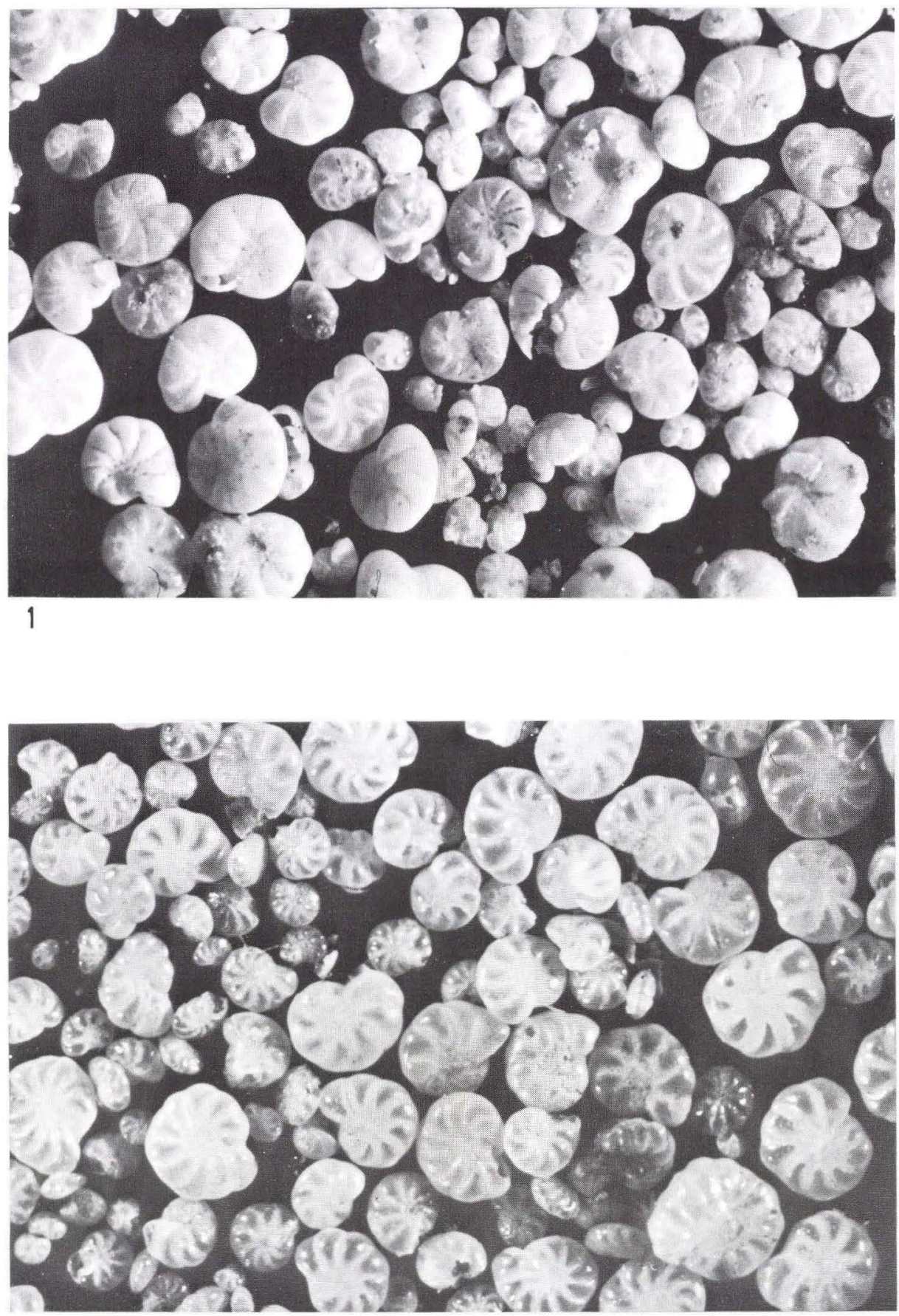


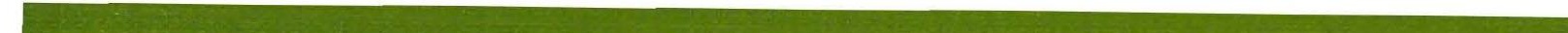

